\title{
Ectopic lignification in primary cellulose-deficient cell walls of maize cell suspension cultures
}

\author{
Hugo Mélida ${ }^{1,2}$, Asier Largo-Gosens ${ }^{1}$, Esther Novo-Uzal ${ }^{3}$, Rogelio Santiago ${ }^{4,5}$, Federico Pomar ${ }^{6}$, Pedro García , \\ Penélope García-Angulo ${ }^{1}$, José Luis Acebes ${ }^{1}$, Jesús Álvarez ${ }^{1}$ and Antonio Encina ${ }^{1 *}$
}

\begin{abstract}
${ }^{1}$ Plant Physiology Laboratory, Faculty of Biological and Environmental Sciences, University of Le, ó, n, E-24071 León, Spain, ${ }^{2}$ Centre for Plant Biotechnology and Genomics (CBGP), Politechnical University of Madrid, E-28223 Madrid, Spain, ${ }^{3}$ Department of Plant Biology, University of Murcia, Murcia 30100, Spain, ${ }^{4}$ Plant Biology and Soil Sciences Department, Faculty of Biology, University of Vigo, Campus As Lagoas Marcosende 36310, Vigo, Spain, ${ }^{5}$ Environmental Agrobiology, Soil and Plant Quality (University of Vigo), Associated Unit to Biological Mission of Galicia (CSIC), ${ }^{6}$ Department of Animal Biology, Plant Biology and Ecology, University of A Coru, ñ, a, E-15071 A Coruña, Spain, ${ }^{7}$ Department of Molecular Biology (Área de Genética), Faculty of Biological and Environmental Sciences. University of León, E-24071 León, Spain.

*Correspondence: a.encina@unileon.es
\end{abstract}

\begin{abstract}
Maize (Zea mays L.) suspension-cultured cells with up to $70 \%$ less cellulose -1 were obtained by stepwise habituation to dichlobenil (DCB), a cellulose biosynthesis inhibitor. Cellulose deficiency was accompanied by marked changes in cell wall matrix polysaccharides and phenolics as revealed by Fourier transform infrared (FTIR) spectroscopy. Cell wall compositional analysis indicated that the cellulosedeficient cell walls showed an enhancement of highly branched and cross-linked arabinoxylans, as well as an increased content in ferulic acid, diferulates and $p$ coumaric acid, and the presence of a polymer that stained positive for phloroglucinol. In accordance with this, cellulosedeficient cell walls showed a fivefold increase in Klasontype lignin. Thioacidolysis/GC-MS analysis of cellulosedeficient cell walls indicated the presence of a ligninlike polymer with a Syringyl/Guaiacyl ratio of 1.45, which differed from the sensu stricto stress-related lignin that arose in response to short-term DCB-treatments. Cene expression analysis of these cells indicated an overexpression of genes
\end{abstract}

specific for the biosynthesis of monolignol units of lignin. A study of stress signaling pathways revealed an overexpression of some of the jasmonate signaling pathway genes, which might trigger ectopic lignification in response to cell wall integrity disruptions. In summary, the structural plasticity of primary cell walls is proven, since a lignification process is possible in response to cellulose impoverishment.

Keywords: Cellulose; dichlobenil; dichlobenil; ectopic lignin; maize Citation: Hugo M Hugo M, Asier L-G Asier L-G, Esther N-U Esther N-U, Rogelio S Rogelio S, Federico P Federico P, Pedro G Pedro G, Penélope G-a Penélope G-a, José Luis A José Luis A, Jesús Á Jesús Á, Antonio E Antonio E (2015) Ectopic lignification in primary cellulose-deficient cell walls of maize cell suspension cultures. J Integr Plant Biol XX:XX-XX doi: 10.1111/jipb.12346

Edited by: Kurt Fagerstedt, Helsinki University, Finland

Received Nov. 28, 2014; Accepted Feb. 25, 2015

Available online on Mar. 4, 2015 at www.wileyonlinelibrary.com/ journal/jipb

() 2015 Institute of Botany, Chinese Academy of Sciences

\section{INTRODUCTION}

The primary cell wall is a complex structure surrounding the protoplasm of elongating plant cells and it is crucial for shape maintenance and directional growth during cell development (Carpita 1996). Moreover, as the outermost layer of the plant cell, it is an active component in response to biotic and abiotic stresses with the capacity to monitor and maintain its integrity by means of structural and compositional changes (Hamann 2014). As with other grasses, the primary cell wall in maize (type II) is mainly composed of a framework of cellulose microfibrils embedded in a matrix of arabinoxylans. Smaller amounts of xyloglucan, mixed-linked glucans, pectins and glycoproteins can also be found as cell wall matrix components (Carpita 1996).

Cellulose, the main load-bearing structure of plant cell walls, is a polymer of $\beta-1,4$ linked glucan chains synthesized by transmembrane protein complexes (Guerriero et al. 2010).
Cellulose is deposited in the cell wall in the form of microfibrils probably composed of 18 or 24 chains (Jarvis 2013). Arabinoxylans, the second major component of maize primary cell walls, play a pivotal role since different populations function by tethering adjacent cellulose microfibrils and forming the matrix phase of cell walls (Scheller and Ulvskov 2010). The arabinoxylan backbone is composed of $\beta-1,4$ linked xylose residues commonly substituted at $\mathrm{C}(\mathrm{O}) 3$ and/or $\mathrm{C}(\mathrm{O}) 2$ with arabinose or (4-O-methyl) glucuronic acid (Fincher 2009). One of the unique features of arabinoxylans from grasses is that the arabinose residues are often esterified at $\mathrm{C}(\mathrm{O}) 5$ with the hydroxycinnamates, ferulic and $p$ coumaric acid. Due to their high reactivity, polysaccharideesterified hydroxycinnamates promote arabinoxylan crosslinking, playing a major role in maintaining the integrity of grass cell walls (Buanafina 2009).

Lignin is a complex phenolic heteropolymer predominantly deposited in the secondarily thickened cell walls of 
specialized plant cell types. Lignin drastically modifies cell wall structure and functions, since after its deposition cell walls acquire hydrophobicity and increase their resistance to mechanical and chemical degradation (Vanholme et al. 2010; Liu 2012) being a key factor in the evolution of tracheophytes vascular system (Lucas et al. 2013). The main building blocks of lignin are the 4-hydroxycinnamyl alcohols (or monolignols): coniferyl and sinapyl alcohols with lesser amounts of $p$ coumaryl alcohol (Boerjan et al. 2003). Monolignols are synthesized in the cytosol from phenylalanine by the phenylpropanoid pathway and transported into the cell wall where they are subjected to oxidative cross-linking by cell wall peroxidases, laccases or otherphenol oxidases using hydrogen peroxide or oxygen as oxidants (Passardi et al. 2004; Fagerstedt et al. 2010; Kärkönen and Kuchitsu 2014). Once polymerized into lignin, p-coumaryl, coniferyl and sinapyl alcohol give rise to $p$-hydroxyphenyl $(H)$, guaiacyl $(G)$ and syringyl (S) units, respectively (Vanholme et al. 2010; Liu 2012).

Lignification is a tightly developmentally regulated process commonly associated with the formation of a secondarily thickened cell wall during cell specialization. Besides, the developmentally regulated lignin, biotic and abiotic stresses can induce unexpected lignification known as ectopic lignification (Caño-Delgado et al. 2000; Moura et al. 2010; Sattler and Funnell-Harris 2013; Miedes et al. 2014). Although there are very few reports in the literature of this phenomenon in exclusively primary-walled cell cultures, ligninlike polymers have been shown to be produced by in vitro model systems under certain conditions (Novo-Uzal et al. 2009; Kärkönen and Koutaniemi 2010; Shen et al. 2013). In some systems, hormonally triggered cells can differentiate into tracheary elements, in which lignin is deposited in the newly formed secondary cell wall (Fukuda and Komamine 1980; Oda et al. 2005). In other cases, triggered cell cultures (normally by sucrose or elicitor treatments) release extracellular lignin into the culture medium (Simola et al.1992; Lange et al. 1995; Nose et al. 1995; Kärkönen et al. 2009).

In the last few decades, a series of different approaches using cellulose biosynthesis inhibitors, mutants or transgenic plants have revealed compensatory effects between cellulose and non-cellulosic components of both primary and secondary cell walls. A reduction in cellulose content or an altered pattern of cellulose deposition has been demonstrated to cause changes in matrix polysaccharides and cell wall ectopic lignification (Caño-Delgado et al. 2000, 2003; Desprez et al. 2002; Ellis et al. 2002; Hernández-Blanco et al. 2007; Bischoff et al. 2009; Hamann et al. 2009; Denness et al. 2011; Brabham et al. 2014). Furthermore, lignin-defective transgenic plants respond with qualitative and quantitative changes in the

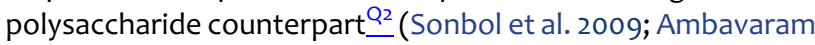
et al. 2011; Fornalé et al. 2012).

In previous studies, maize cell lines habituated to otherwise lethal concentrations of DCB (2,6-dichlorobenzonitrile, dichlobenil), a well-known cellulose biosynthesis inhibitor, were obtained by means of incremental exposure over many culturing cycles (Mélida et al. 2009; de Castro et al. 2014). These cell cultures had the capacity to cope with DCB through the acquisition of a modified cell wall in which the cellulosic scaffold was completely or partially replaced by a more extensive network of highly cross-linked arabinoxylans (Mélida et al. 2009 2010a, 2010b, 2011). Our preliminary data indicated that DCB habituation could also induce ectopic lignification (as cellulose-deficient walls from habituated cells resulted positively for phloroglucinol staining) as a consequence of a reduction in cellulose in maize cells. An indepth characterization of this phenomenon could further our understanding of the chemical composition of ectopic lignin and the relationship between ectopic lignification and stress responses. In this study, we characterized cell walls from maize suspension-cultured cells habituated to low $(1 \mu \mathrm{M})$ and high $(6 \mu M)$ DCB concentrations and from DCB shortterm treated cell suspensions $\left(I_{50}\right.$ value for maize suspension cultured cells is $0.5 \mu \mathrm{M} \mathrm{DCB}$; de Castro et al. 2014), paying special attention to the putative ectopic lignin/ligninlike component as well as the expression levels of genes specific for the biosynthesis of monolignol units of lignin and others involved in common stress signaling pathways.

\section{RESULTS}

\section{Cell wall fingerprinting indicated increased phenolics-to- polysaccharides ratios due to $D C B$ exposure}

FTIR spectra of non-habituated (SNH), DCB short-term treated $(\mathrm{SNH}+\mathrm{DCB})$ and habituated to (SH1) 1 and (SH6) $6 \mu \mathrm{M} \mathrm{DCB}$ maize suspension-cultured cells were obtained, normalized and baseline corrected. Averaged difference spectra were obtained by digital subtraction of SNH spectra from each of the DCB-treated/habituated cell lines (Figure 1). Compared with SNH spectra, those from both short-term treated and habituated cell walls showed negative peaks in the region ranging from 900 to $1,200 \mathrm{~cm}^{-1}$ where most of the cell wall polysaccharides, including cellulose, absorb (Alonso-Simón et al. 2011; Largo-Gosens et al. 2014). In addition, positive peaks were detected associated with wave numbers indicative of aromatic rings $\left(1,515,1,600\right.$ and $\left.1,630 \mathrm{~cm}^{-1}\right)$, phenolic rings $\left(1,500 \mathrm{~cm}^{-1}\right)$ and phenolic esters $\left(1,720 \mathrm{~cm}^{-1}\right)$ (Kačuráková et al. 2000), indicating that both DCBtreated and DCB-habituated cells were enriched in phenolics. In accordance with this, wave number ratios 1,540/1,160; 1,540/ 1,425 and $1,540 / 1,740 \mathrm{~cm}^{-1}$ normally associated with increased lignin-to-polysaccharides ratios raised in both DCB-treated and DCB-habituated cells (Table 1).

\section{Highly branched and cross-linked arabinoxylans increased in parallel to the DCB habituation process}

Cell wall fractionation showed that in both DCB-treated and DCB-habituated cells, most of the non-cellulosic cell wall polysaccharides (70-80\%) corresponded to $\mathrm{KOH}$ extractable hemicelluloses, namely $\mathrm{KI}$ and $\mathrm{KII}$ fractions (Figure S1). Moreover, differences were observed in cell wall fractionation among cell lines. Of particular note was the increase in strong alkali-extracted hemicelluloses (KII fraction: $29 \%$ in $\mathrm{SNH}$ vs. $42 \%$ in SH6) exclusively associated with habituation to high DCB concentrations (Figure S1).

The monosaccharide composition of each of the fractions was determined by gas chromatography and spectrophotometric methods (Figure 2). The CDTA-pectic fraction was enriched in uronic acids, and minor amounts of the neutral sugars Ara, Xyl, Gal and Glc were also detected (Figure 2A). The abundance of uronic acids compared to neutral sugars indicated the presence in the CDTA fraction of homopolymers 

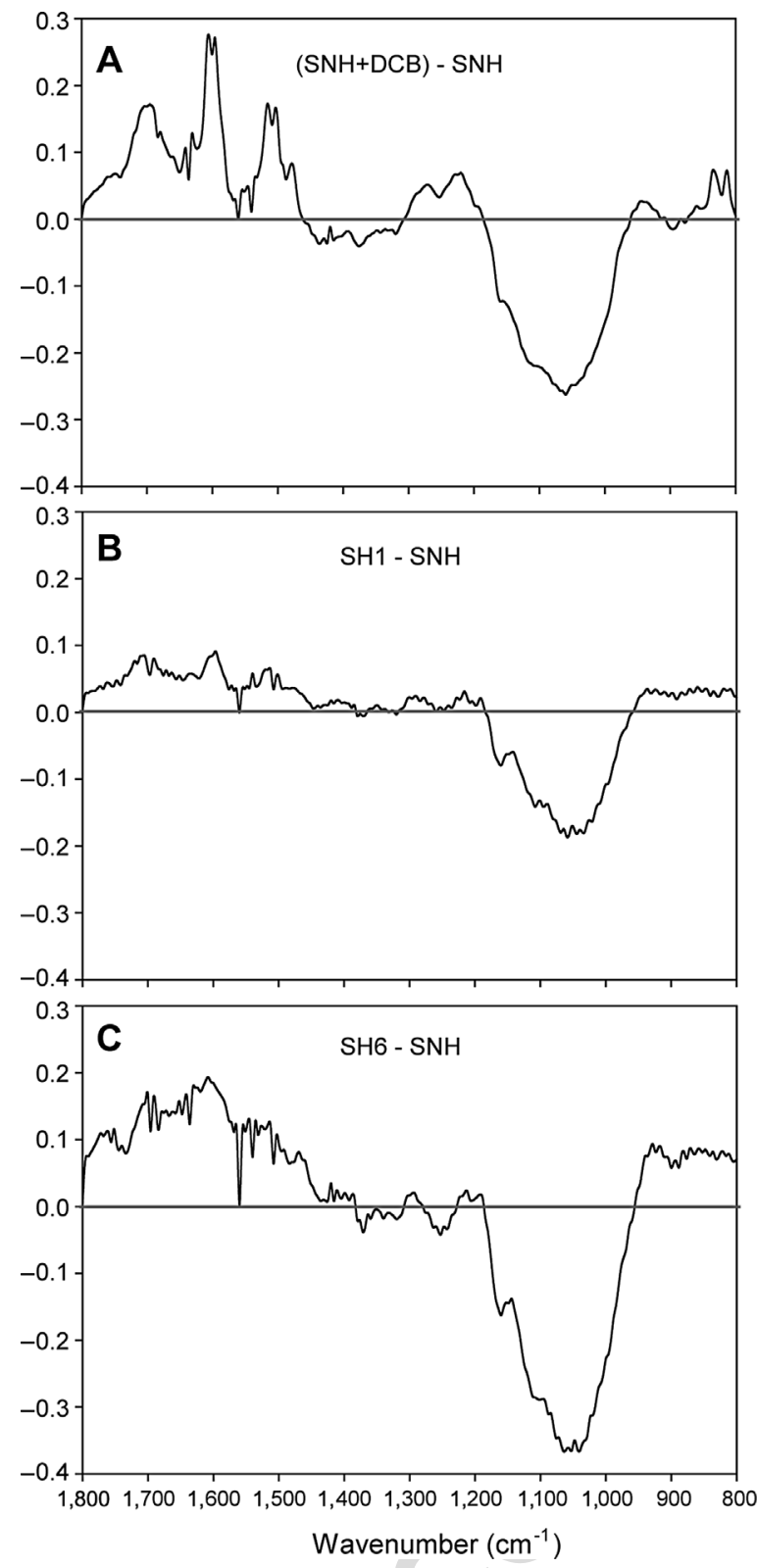

Figure 1. Fourier transform infrared (FTIR) analysis of cell walls

Averaged FTIR difference spectra obtained after digital subtraction of the spectra of non-habituated $(\mathrm{SNH})$ cell wall FTIR spectra from SNH + dichlobenil (DCB), SH1 or SH6 cell wall FTIR spectra. Maize cell lines were annotated as follow: non-habituated (SNH); DCB short-term treated (SNH + DCB), habituated to $1 \mu \mathrm{M} \mathrm{DCB}(\mathrm{SH} 1)$ or habituated to $6 \mu \mathrm{M} \mathrm{DCB}$ (SH6) maize cell suspension-cultured cells.

based on the acidic sugars (i.e. homogalacturonan). However, only minor differences in the CDTA fraction were found between $\mathrm{SNH}$ and the rest of the lines. $\mathrm{KOH}$ extracted hemicelluloses were mainly composed of Ara, Xyl and uronic acids, indicative of (glucurono-) arabinoxylans and/
Table 1. Fourier transform infrared (FTIR) wave number ratios characteristic of lignin and cell wall polysaccharides

\begin{tabular}{lcccc}
\hline FTIR peak & & & & \\
height ratio & SNH & SNH + DCB & SH1 & SH6 \\
\hline $1540 / 1160 \mathrm{~cm}^{-1}$ & 0.09 & 0.14 & 0.13 & 0.21 \\
$1540 / 1425 \mathrm{~cm}^{-1}$ & 0.16 & 0.21 & 0.19 & 0.28 \\
$1540 / 1740 \mathrm{~cm}^{-1}$ & 0.16 & 0.18 & 0.18 & 0.25 \\
\hline
\end{tabular}

Peak assignations $\underline{Q}, 1,160 \mathrm{~cm}^{-1}, \mathrm{C}-\mathrm{O}-\mathrm{C}$ vibration of the glycosidic link in cellulose, xyloglucan or pectic polysaccharides; $1,425 \mathrm{~cm}^{-1}, \mathrm{C}-\mathrm{H}$ stretching in $\mathrm{CH}_{2}$ groups of cellulose; $1,540 \mathrm{~cm}^{-1}$, aromatic ring stretching in lignin; $1,740 \mathrm{~cm}^{-1}, \mathrm{C}-\mathrm{O}$ stretch in ester groups.

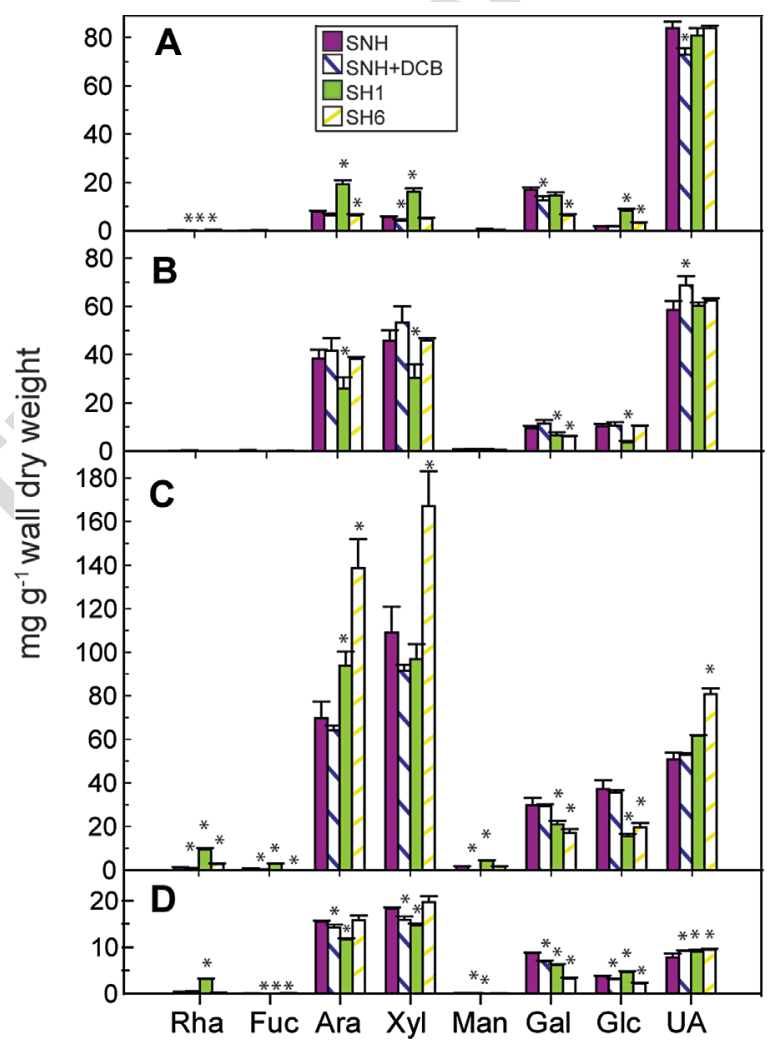

Figure 2. Cell wall sugar analysis

Sugar composition of (A) CDTA, (B) KI, (C) KII and (D) trifluoroacetic acid (TFA) cell wall fractions obtained from (open square) spectra of non-habituated (SNH), (light grey square) $\mathrm{SNH}+$ dichlobenil (DCB), (dark grey square) $\mathrm{SH} 1$ and (black square) SH6 cell lines. For maize cell line annotations see Figure 1 legend. Ara (arabinose), Fuc (fucose), Gal (galactose), Glc (glucose), Man (mannose), Rha (rhamnose), UA (uronic acids), Xyl (xylose). Data represents the means values \pm standard deviation (SD) of three technical replicates. Asterisks indicate values that are significantly different from SNH after a Student's t-test $(P<0.05)$. 
Table 2. Arabinose and xylose content in the KII fractions

\begin{tabular}{llll}
\hline & \multicolumn{2}{c}{ (\%) Ara + Xyl } & \\
\cline { 2 - 3 } & Cell wall & $\begin{array}{l}\text { Kll-extracted } \\
\text { sugars }\end{array}$ & Ara:Xyl ratio \\
\hline SNH & $17.9 \pm 0.9$ & $59.5 \pm 1.7$ & 0.64 \\
SNH+DCB & $15.6 \pm 0.5$ & $56.7 \pm 0.3$ & 0.70 \\
SH1 & $19.1 \pm 1.3$ & $62.4 \pm 0.8$ & 0.97 \\
SH6 & $\mathbf{3 0 . 6} \pm \mathbf{2 . 9}$ & $\mathbf{7 1 . 5} \pm \mathbf{1 . 4}$ & 0.83 \\
\hline
\end{tabular}

Mean values \pm standard deviation (SD) of three technical replicates per line. For cell line annotation see Figure 1 legend.

or acidic pectins associated to arabinoxylans (de Castro et al. 2014), followed by minor amounts of Gal and Glc (Figure 2B, C). Quantitatively, KII represented the main fraction, and a monosaccharide analysis revealed an increase in the Ara and Xyl proportions associated with habituation to DCB (especially with high concentrations), but not with short-term exposures (Figure 2C; Table 2). The observed increase in the Ara-toXyl ratio detected in $\mathrm{SH} 1$ and $\mathrm{SH} 6$ when compared with $\mathrm{SNH}$, indicated not only a quantitative increase in heteroxylans but also the presence of highly substituted xylan populations (Table 2). The final residues after CDTA and alkali extractions were TFA-hydrolyzed. Gas chromatography analysis of the TFA fraction resembled that from $\mathrm{KI}$ fraction with lesser proportions of the acidic sugars, suggestive of alkaliresistant heteroxylans (Figure 2D). No differences among cell lines were found for this fraction.

Cellulose reduction is a consequence of habituation to DCB Cellulose averaged approximately $25 \%$ of the cell wall dry weight when assayed in SNH cells (Figure 3). Cellulose content

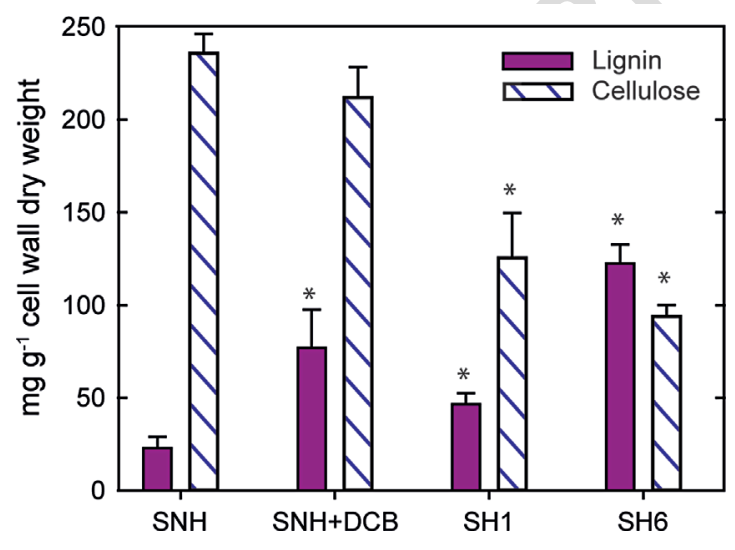

Figure 3. Comparison of cellulose and lignin content in spectra of non-habituated (SNH), SNH + dichlobenil (DCB), SH1 and SH6 cell lines

For maize cell line annotations see Figure 1 legend. Data represents means \pm standard deviation (SD) of at least four replicates. Asterisks indicate values that are significantly different from SNH after a Student's t-test $(P<0.05)$. decreased along DCB-habituated cells in a dosedependent manner, up to the 50 and $70 \%$ reduction found, respectively, in $\mathrm{SH} 1$ and $\mathrm{SH} 6$ cells when compared with $\mathrm{SNH}$ cells (Figure 3). However, short-term incubations with the cellulose biosynthesis inhibitor did not induce significant reductions in cellulose content. On the other hand, these short-term incubations did increase the amount of a Klasonresistant residue, which could be associated with lignin or a lignin-like phenolic-rich material (Figure 3). This ligninlike material was also found to be increased in the cell wall of the DCB-habituated cells. Indeed, $\mathrm{SH}_{1}$ and $\mathrm{SH} 6$ cells contained approximately 2 to 5 times more of this residue, respectively, when compared with the SNH counterpart (Figure 3).

\section{Cell wall phenolic profile}

Maize primary cell wall typically contains high levels of wallesterified phenolics, which appear as side-chain decorations of arabinoxylans. $p$-Coumarate, ferulate and their oxidative coupling products, diferulates, increased steeply over the course of the DCB habituation process (Table 3). In comparison with $\mathrm{SNH}, \mathrm{SH} 1$ and $\mathrm{SH} 6$ cell walls were enriched in the $5,5^{\prime}, 8,5^{\prime}$ and specially the $8-0-4^{\prime}$ form of diferulates. In all cases, enrichment was more noticeable in SH6 cells.

In comparison to SNH cells, trends similar to those for the DCB-habituated cells were observed when the phenolic profile of DCB short-term treated cells was analyzed (Table 3). Most notably, there was a marked increase in cell wall esterified $p$ coumarate, with SNH+DCB cells being 132- and 15fold enriched in $p$-coumarate when compared with $\mathrm{SNH}$ and SH6 cells, respectively.

DCB induced the deposition of lignin-like polymers in maize cultured cells

Phloroglucinol- $\mathrm{HCl}$, which specifically stains 4-Olinked hydroxycinnamyl aldehyde residues of lignin (Pomar et al. 2002), was used to preliminarily confirm the presence of a lignin-like phenolic-rich material in the cell walls of DCB short-term treated and habituated cells. This strategy demonstrated that lignin accumulation depended on the presence of DCB in the culture medium (Figure 4); maize suspension-cultured cells stained negative for phloroglucinol when cultivated in a medium lacking DCB (Figure $4 A$ ). In the case of maize cells were incubated short-term in $6 \mu \mathrm{M} \mathrm{DCB}$

Table 3. Cell wall esterified phenolics composition

\begin{tabular}{|c|c|c|c|c|c|c|}
\hline & \multirow[b]{2}{*}{ p-Coumarate } & \multirow[b]{2}{*}{$\begin{array}{r}\text { Ferulate } \\
\text { mg g }\end{array}$} & \multicolumn{4}{|c|}{ Diferulates } \\
\hline & & & $\begin{array}{l}\text { Tota } \\
-1 \text { cell }\end{array}$ & $\begin{array}{l}5,5^{\prime}- \\
\text { vall }\end{array}$ & $8-0-4^{\prime}-$ & $8,5^{\prime}-{ }^{a}$ \\
\hline SNH & 0.21 & 0.82 & 1.83 & 0.48 & 0.76 & 0.59 \\
\hline $\mathrm{SNH}+\mathrm{DCB}$ & 27.80 & 6.60 & 2.33 & 0.56 & 1.20 & 0.57 \\
\hline $\mathrm{SH} 1$ & 0.52 & 11.55 & 2.29 & 0.54 & 1.13 & 0.62 \\
\hline SH6 & 1.83 & 17.71 & 3.58 & 1.07 & 1.58 & 0.93 \\
\hline
\end{tabular}

Mean values from two independent experiments per cell line. For cell line annotation see Figure 1 legend. a $8,5^{\prime}$ diferulate was calculated as the sum of 8-5-open and 8-5 benzofurans forms. 

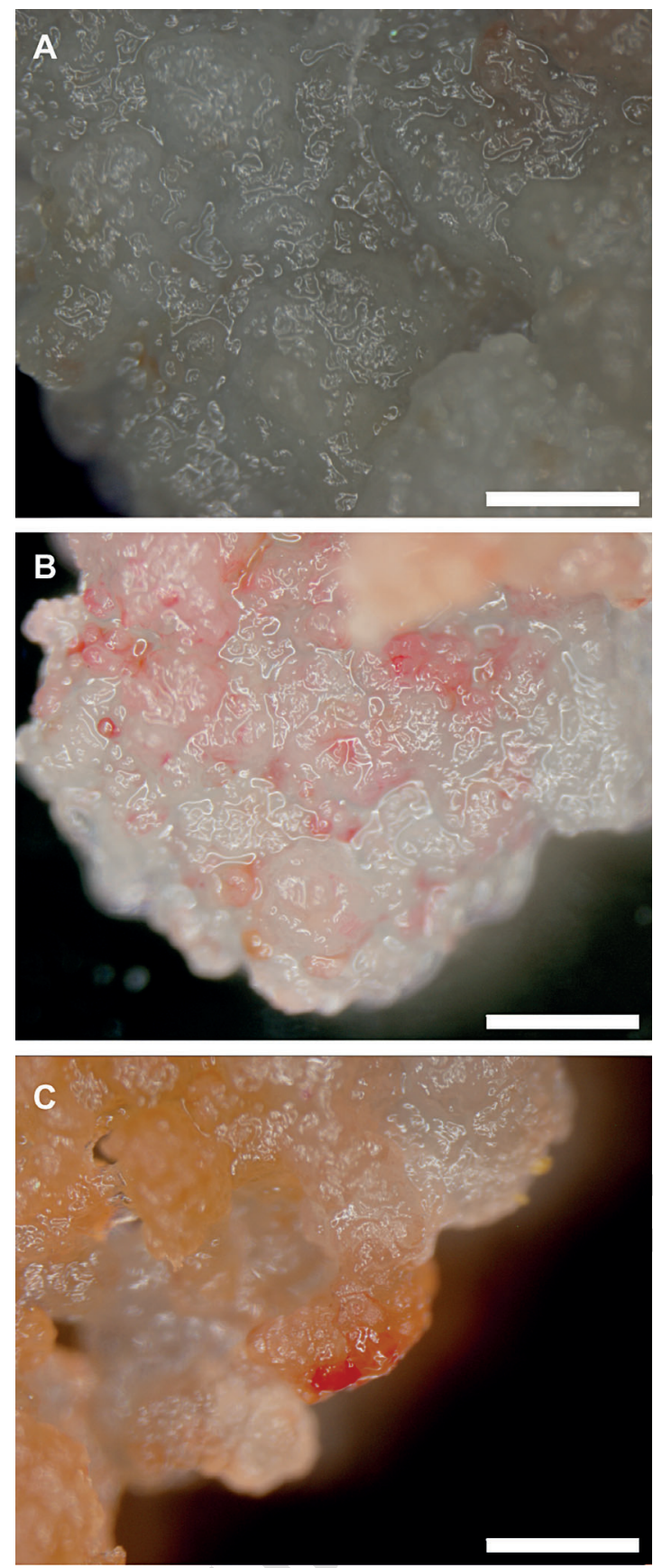

Figure 4. Phloroglucinol/HCl staining of spectra of nonhabituated (SNH), SNH + dichlobenil (DCB), and SH6 cells For maize cell line annotations see Figure 1 legend. Bar $=0.5 \mathrm{~mm}$.

(Figure 4B) and DCB-habituated cells (Figure 4C), positive phloroglucinol staining was observed on the surface of cellaggregates. No evidence of differentiation into tracheary elements were observed in any case (data not shown).

The presence of lignin-like polymers was further confirmed by thioacidolysis followed by gas chromatography coupled to mass spectrometry (GC-MS) of the cleavage products. This analysis also confirmed the presence of trace amounts of sinapyl alcohol (S units) in SNH, SNH+DCB and $\mathrm{SH}_{1}$ cell walls (Figure 5B, D and data not shown). In addition to the $S$ units, measurable amounts of coniferyl alcohol ( $G$ units) were detected in SH6 cell walls, but not in the other cell lines (Figure 5E, F). Indeed, S units were (semi-quantitatively) estimated to be more abundant in SH6 than in any other cell line. Based on thioacidolysis results, an S/G ratio of 1.45 was estimated for the SH6 lignin-like material (Table 4).

\section{Lignin biosynthesis-specific genes are overexpressed in DCB-habituated cells}

In a previous study by our group, we demonstrated that the genes functioning in the initial steps of the phenylpropanoid pathway (Phenylalanine Ammonia-Lyase, Cinnamate 4-Hydroxylase, 4-Coumarate $\mathrm{COA}$ Ligase, HydroxycinnamoylCoA Shikimate/quinate hydroxycinnamoyl Transferase and Caffeic acid O-Methyltransferase) are overexpressed in DCBhabituated cells (Mélida et al. 2010a). The corresponding proteins from such genes are involved in the production of $p$ coumaroyl-CoA and feruloyl-CoA, the substrates for hydroxycinnamate esterification of arabinoxylans (Lindsay and Fry 2008). Given the evidence of the presence of ligninlike polymers in DCB-habituated cells, quantitative RT$P C R$ was used to monitor the transcript abundance of cinnamoyl-COA reductase (CCR), ferulate 5-hydroxylase $\left(\mathrm{F}_{5} \mathrm{H}\right)$ and cinnamyl alcohol dehydrogenase (CAD), involved in the last steps of monolignol synthesis (Figures 6, 7).

A general overexpression of the two $Z m C C R$ genes was observed in DCB-habituated cell lines (Figure 6A, B), whereas short-term treatment with $D C B$ induced only minor changes in $Z m C C R 1$ and $Z m C C R 2$ mRNA levels. The expression of $\mathrm{ZmF}_{5} \mathrm{H}_{2}$ was significantly increased in all cell lines when compared with SNH cells, and this enhancement was especially noticeable in DCB-habituated lines (Figure 6D). In the case of $\mathrm{ZmF}_{5} \mathrm{H}_{1}$, only $\mathrm{SH} 1$ cells showed higher transcript abundance, and indeed this gene was repressed in SNH+DCB and SH6 (Figure 6C). Both $D C B$ short-term treatment and $D C B$ habituation induced an overexpression of $Z m C A D 1, Z m C A D 5$ and $Z m C A D 7$ genes in comparison with SNH cells (Figure 7A, D, F). This enhancement was especially marked in the case of $Z m C A D 7$ transcript levels in $\mathrm{SH} 1$ cells, whereas the abundance of ZmCAD6 transcripts was only significantly increased in habituated cells (Figure $7 \mathrm{E}$ ). Moreover, there was a high overexpression (12-fold) of ZmCAD2 in SH6 cells; however, the transcript levels of this gene were significantly reduced in $\mathrm{SH}_{1}$ cells (Figure $7 \mathrm{~B}$ ). Surprisingly, there was a significant repression of the transcript levels coding for $\mathrm{ZmCAD} 3$ in $\mathrm{DCB}$-habituated cell lines (Figure $7 C$ ). The $Z m C A D 4$ transcription levels were too low to be accurately quantified by this procedure. Given the general overexpression of the genes coding for $C A D$ proteins in response to $D C B$, we measured $C A D$ activity in the different cell lines (Figure $7 G$ ). CAD activity assayed from cell extracts was significantly increased in SNH+DCB and SH6 when compared with $\mathrm{SNH}$ cell lines, but unchanged in the case of SH1 cells.

\section{Apoplastic hydrogen peroxide accumulation}

Both DCB short-term treated and DCB-habituated cells accumulated significantly more $\mathrm{H}_{2} \mathrm{O}_{2}$ in the spent medium 


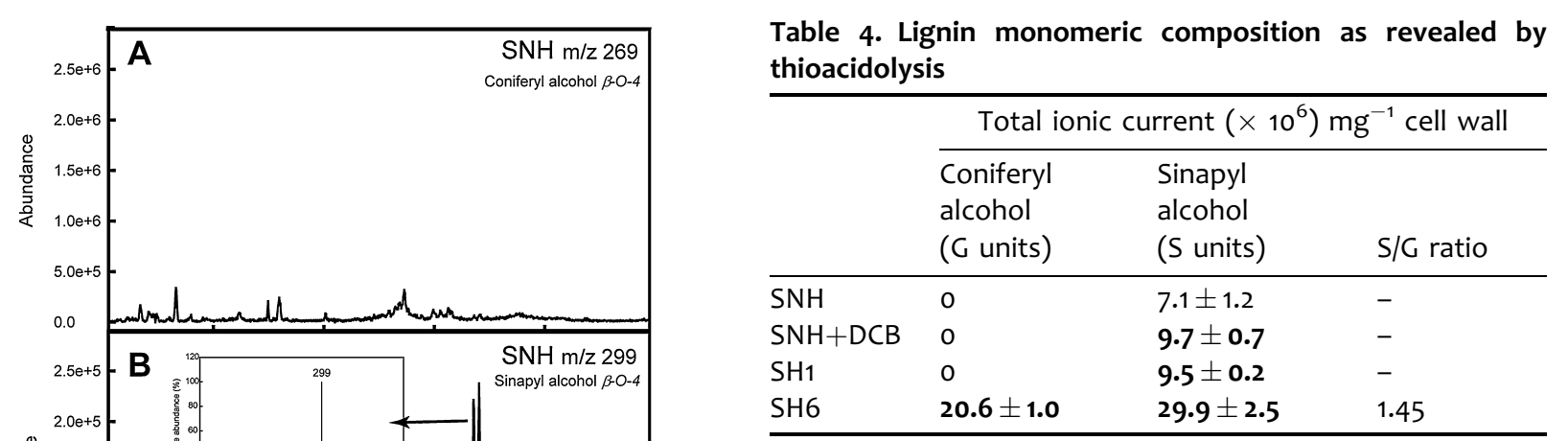

Mean values \pm standard deviation (SD) of three replicates per cell line. For cell line annotation see Figure 1 legend. Values

than SNH cells (Table 5), although there is no clear relationship between $\mathrm{H}_{2} \mathrm{O}_{2}$ accumulation and the presence of ligninlike polymers. SH6 cells, which showed the strongest ectopic lignification, did not peak in $\mathrm{H}_{2} \mathrm{O}_{2}$ content when compared with $\mathrm{SH} 1$ or $\mathrm{SNH}+\mathrm{DCB}$ cells. In fact, $\mathrm{SH} 6$ cells accumulated less $\mathrm{H}_{2} \mathrm{O}_{2}$ during the lag and exponential phases than $\mathrm{SH}_{1}$ or $\mathrm{SNH}+\mathrm{DCB}$ cells.

\section{JA synthetic and JA signalling pathways overexpressed}

To determine whether the accumulation of lignin-like material formed part of an abiotic stress response mechanism, RTPCR was used to monitor the expression levels of several genes from the jasmonic acid (JA) and salicylic acid (SA) stress signaling pathways (Figure 8). Three 12oxophytodienoate reductase (OPR) genes, coding for proteins involved in the synthesis of JA, were analyzed. Two of them (ZmOPR1 and ZmOPR2) were always overexpressed in the presence of DCB, but ZmOPR7 was only overexpressed in DCBhabituated cell lines, and was slightly repressed by the shortterm exposure of SNH cells to DCB (Figure 8). NADPH oxidase (NADPHOX) and maize protease inhibitor (MPI) genes are reported to be $J A$-induced in response to abiotic stresses (Shivaji et al. 2010). The results showed that both genes were overexpressed in the presence of DCB.

For the SA stress signaling pathway, pathogenesis related protein 1 (PR1) and non-expressor of PR1 (NPR1) genes were studied. The ZmNPR1 gene was detected, but there were no differences in the expression pattern induced by either $D C B$ exposure or $D C B$ habituation. ZmPR1 transcripts were not detected in any cell line.

\section{DISCUSSION}

In their natural habitats, plant cells must continuously remodel their cell walls in order to grow and to interact with the environment. In order to understand the limits of these interactions, plant cells can be cultivated in fully controlled experimental systems where their capacity to cope with different situations can be better studied. The habituation of plant cell cultures to cellulose biosynthesis inhibitors such as DCB represents a valuable tool to improve our knowledge of the mechanisms involved in plant cell wall structural plasticity (Shedletzky et al. 1992; Encina et al. 2002;

\section{Figure 5. Lignin monomer composition}

Gas chromatography (GC) profiles of the thioethylated monomers (erythro and threo isomers) arising from arylglycerol-b-aryl ether ( $\beta$-O-4) structures derived from (A, C and E) coniferyl and (B, D and F) sinapyl alcohols from cell walls of (A, B) SNH; (C, D) SNH+DCB; and (E, F) SH6 cell lines. For maize cell line annotations see Figure 1 legend. 


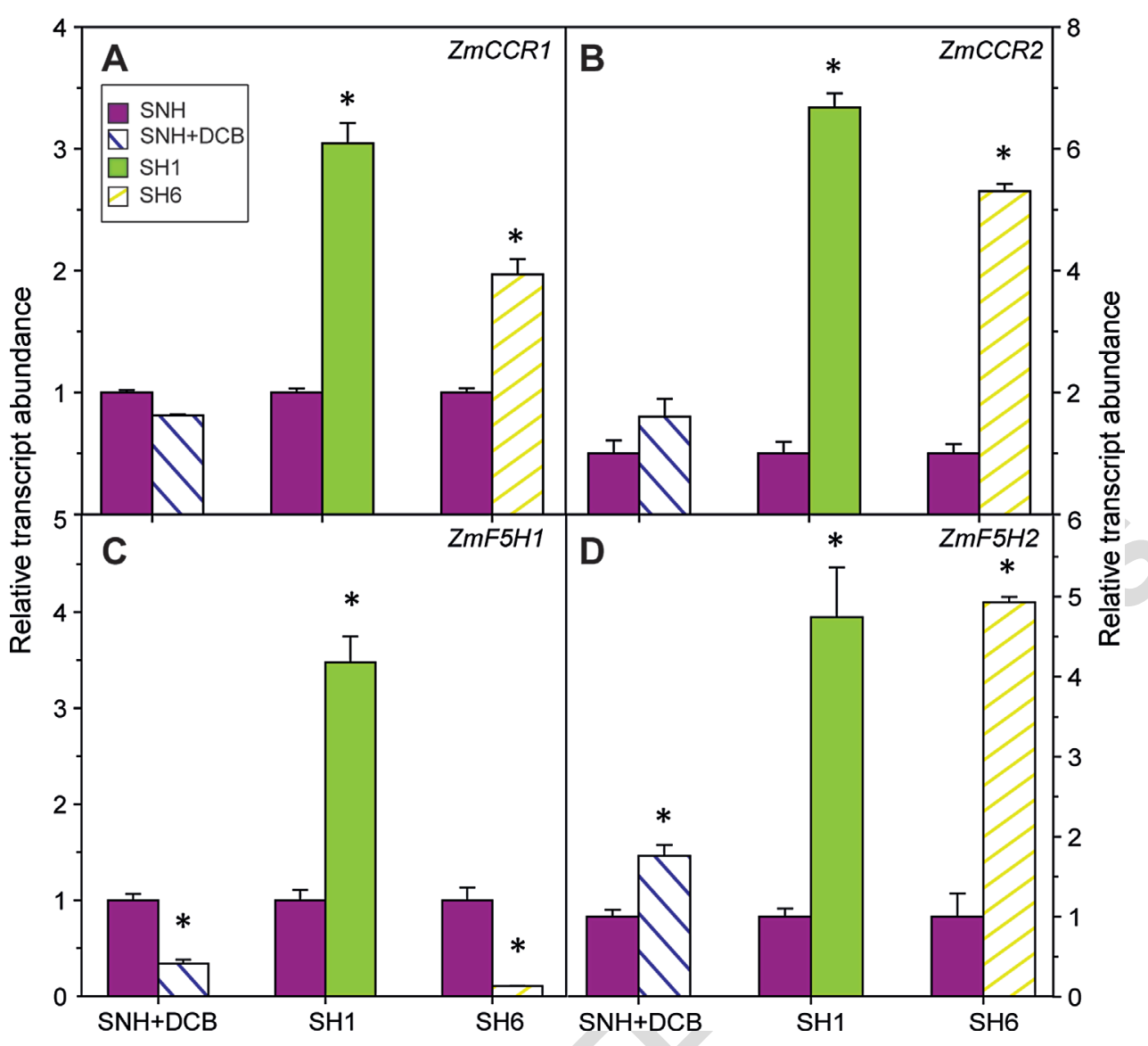

Figure 6. Quantitative reverse transcription-polymerase chain reaction (qRT-PCR) characterization of (A, B) ZmCCR and (C, D) $\mathrm{ZmF}_{5} \mathrm{H}$ genes of spectra of non-habituated (SNH), SNH + dichlobenil (DCB), SH1 and SH6 cell lines

The gene expression levels of SNH+DCB, SH1 and SH6 cell lines were always compared against the SNH ones, which are represented as left-sided bars. For maize cell line annotations see Figure 1 legend. Data represent relative fold change relative to $\mathrm{SNH}$ genes \pm standard deviation (SD) of three replicates. Asterisks indicate values that are significantly different from SNH after a Student's t-test $(P<0.05)$.

Manfield et al. 2004; García-Angulo et al. 2009; Mélida et al. 2009; Brochu et al. 2010; de Castro et al. 2014, 2015).

In previous studies, we have shown that the habituation of maize cells to $D C B$ involves several metabolic modifications (Mélida et al. 2010a; de Castro et al. 2014, 2015). Maize cells habituated to high DCB levels ( $\geq 30$ times higher than DCB $I_{50}$ value) display strong reduction in cellulose and altered expression of several Cellulose Synthase genes (Mélida et al. 2009; 2010a). Although DCB induces oxidative damage (based on lipid peroxidation levels in maize cultured cells; unpublished results), given the level of detoxifying/antioxidant activities measured, it seems that DCB-habituated maize cells do not rely on an antioxidant strategy to cope with this herbicide, which contrasts with the strategy observed in cells of other species, such as bean, in which antioxidant capacity is enhanced when habituated to DCB (García-Angulo et al. 2009; Mélida et al. 2010a). Indeed, the ability of maize cells to grow under high DCB concentrations resides mainly in their capacity to reorganize their cell wall architecture. Through compositional analysis and structural characterization of DCB- habituated cell walls, it has been possible to demonstrate that these cells compensate for cellulose impoverishment with other cell wall components. The mechanism for this accommodation consists of producing a more extensive, cross-linked network of arabinoxylans (Mélida et al. 2009; 2010a, 2010b, 2011). More recently, we have found that some of the cell wall modifications differ according to DCB habituation level (de Castro et al. 2014).

In this study, we used maize cell suspension cultures habituated to low ( $1 \mu \mathrm{M}$ DCB, SH1) and high ( $6 \mu \mathrm{M}$ DCB, SH6) levels of $D C B$ as well as non-habituated cells treated for a short time with lethal doses of the herbicide $(\mathrm{SNH}+6 \mu \mathrm{M}$ DCB). In agreement with previous studies, we have shown that habituated cell lines display dose-dependent reductions in their cellulose content. These cellulose reductions (up to $70 \%$ less than in $\mathrm{SNH}$ ) were compensated by a more extensive network of arabinoxylans, which could only be extracted with strong alkali.

In line with previous results obtained for maize callus cultures habituated to high DCB concentrations (Mélida et al. 


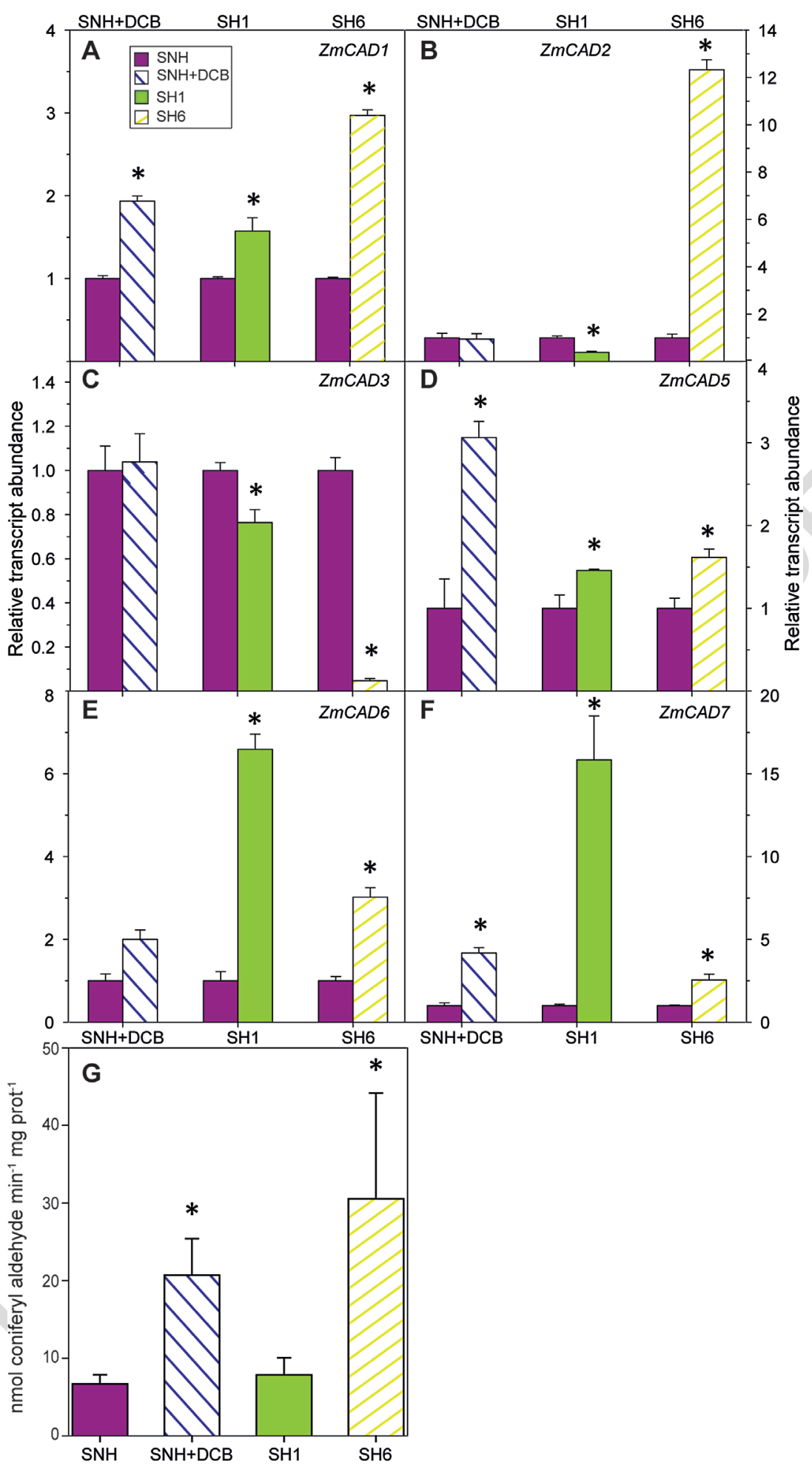

Figure 7. Quantitative reverse transcription-polymerase chain reaction (qRT-PCR) characterization of (A-F) ZmCAD genes and (G) CAD enzyme activity assay of spectra of non-habituated (SNH), SNH + dichlobenil (DCB), SH1 and SH6 cell lines

The gene expression levels of SNH+DCB, SH1 and SH6 cell lines were always compared against the SNH ones, which are represented as left-sided bars. For maize cell line annotations see Figure 1 legend. For A-F, data represent relative fold change relative to $S N H$ genes \pm standard deviation (SD) of three replicates. For $G$, data represents means \pm SD of at least nine replicates. Asterisks indicate values that are significantly different from SNH after a Student's $t$-test $(P<0.05)$. ZmCAD4 mRNA transcripts were not detected. 
Table 5. Apoplastic $\mathrm{H}_{2} \mathrm{O}_{2}$ concentration measured in the spent medium of the different cell lines

\begin{tabular}{|c|c|c|c|}
\hline & $\begin{array}{l}\text { Lag } \\
\text { phase }\end{array}$ & $\begin{array}{l}\text { Exponential } \\
\text { phase }\end{array}$ & $\begin{array}{l}\text { Stationary } \\
\text { phase }\end{array}$ \\
\hline & \multicolumn{3}{|c|}{$\mathrm{H}_{2} \mathrm{O}_{2}(\mu \mathrm{M})$} \\
\hline SNH & $0.4 \pm 0.3$ & $0.8 \pm 0.1$ & $0.6 \pm 0.1$ \\
\hline $\mathrm{SH} 1$ & $1.9 \pm 0.3$ & $2.4 \pm 0.2$ & $2.3 \pm 0.2$ \\
\hline SH6 & $0.8 \pm 0.1$ & $1.7 \pm 0.5$ & $2.4 \pm 0.2$ \\
\hline Incubation time & 1 day & 6 days & \\
\hline $\mathrm{SNH}+\mathrm{DCB}$ & $1.0 \pm 0.1$ & $2.0 \pm 0.1$ & \\
\hline
\end{tabular}

Mean values \pm standard deviation (SD) of three replicates per line. Values were obtained at the different growth phases for each line. Short-term treated cells (SNH+DCB) were measured 1 day and 6 days after the addition of DCB. Values

2010b; 2011), we found that hydroxycinnamates, the arabinoxylan cross-linkers, experienced quantitative changes that indicated a prominent role of these compounds in a cellulosedeficient cell wall. This is actually one of the singularities of this model system. Most of the cell lines habituated to cellulose biosynthesis inhibitors (or other cell wall stresses) have had type I primary cell walls (i.e. Arabidopsis, poplar, bean, tomato), where cellulose reductions were compensated by pectins (Shedletzky et al. 1990; Encina et al. 2002; Manfield et al. 2004; Brochu et al. 2010). In contrast to type I, type II primary cell walls are characterized by the presence of phenylpropanoids (mainly ferulic and $p$-coumaric acids), which have an important role in cross-linking hemicelluloses (Wallace and Fry 1994). Ferulate and its dimers increased steeply over the course of the DCB habituation process, but it was the changes in the proportions of esterified $p$-coumarate, which indicated that something else was happening. Indeed, in this case the changes observed for the shortterm treatments were quite striking, as SNH+DCB cells were 132-and 15-fold enriched in $p$-coumarate when compared with SNH and SH6 cells, respectively. In the case of maize plants, small amounts of $p$-coumaric acid are esterified to arabinoxylans in primary walls, but later on in wall development, it is found more extensively esterified to lignin (liyama et al. 1994; Ralph et al. 1994a). Indeed pcoumarate incorporation into the cell wall has been positively correlated with lignification (Hatfield and Marita 2010).

These findings suggest the presence of ectopic lignin or lignin-like polymers at least in the case of short-term treated cells, where the induced stress would explain their presence. Surprisingly, not only the short-term treated cells but also the DCB-habituated ones displayed a pink to brownish colour after phloroglucinol staining, indicative of lignin or ligninlike polymers (Pomar et al. 2002).

Our results clearly show the presence of ectopic lignin in maize primary cell walls of both DCB-habituated and short-

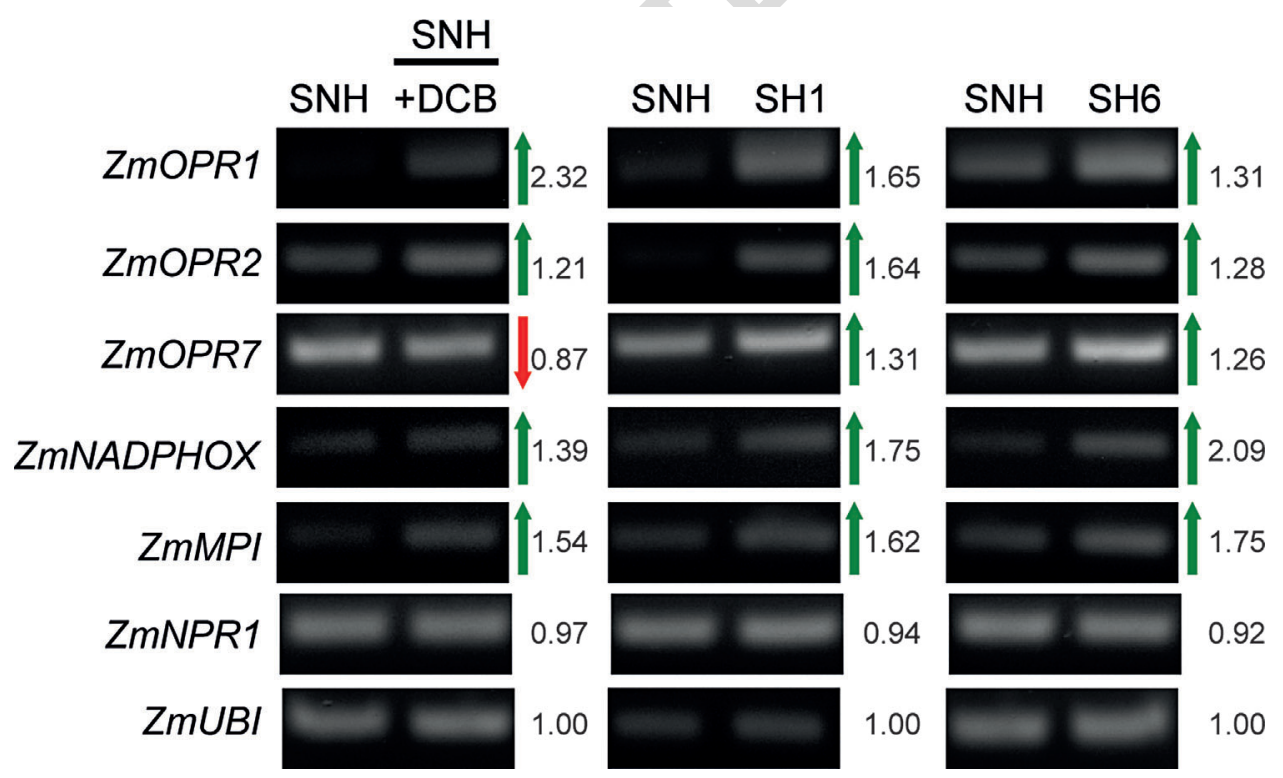

Figure 8. Relative expression levels of jasmonic acid (JA) and salicylic acid (SA) signaling pathways genes analyzed by reverse transcription-polymerase chain reaction (RT-PCR) of spectra of non-habituated (SNH), SNH + dichlobenil (DCB), SH1 and SH6 cell lines

For maize cell line annotations see Figure 1 legend. á and â indicate less and more mRNA accumulation than SNH cells, respectively. 12-oxophytodienoate reductase (ZmOPR1, ZmOPR2 and ZmOPR7), NADPH oxidase (ZmNADPHOX), maize protease inhibitor (ZmMPI), and nonexpressor of pathogenesis related protein 1 (ZmNPR1). Pathogenesis related protein 1 (ZmPR1) was not detected. Primers can be found in Supplemental Table S1. Numerals indicate the normalised ratios of RT-PCR band intensities calculated by dividing the band intensity of SNH+DCB, SH1 or SH6 by SNH for each gene. 
term treated cells. Therefore, phenolics not only act as hemicellulose cross-linking units in this system, but also constitute monolignol-based polymers similar to lignin that might contribute to stiffening of a celluloseimpoverished wall. Although ectopic lignification has been observed in Arabidopsis mutants with reduced cellulose synthesis and in seedlings treated with cellulose biosynthesis inhibitors (Caño-Delgado et al. 2003; Bischoff et al. 2009; Denness et al. 2011), there are few reports of this phenomenon in exclusively primary-walled cell cultures (Ros Barceló 1997). Moreover, transcriptomic approaches using Arabidopsis and poplar cell cultures habituated to cellulose biosynthesis inhibitors have shown that several genes specifically involved in lignin synthesis are downregulated (Manfield et al. 2004; Brochu et al. 2010). Lignin-like polymers have been shown to be produced by other in vitro model systems under certain conditions (Kärkönen and Koutaniemi 2010). However, although these systems achieve lignin production in plant cultured cells, ectopic lignin deposition in primary cell wall, the feature of cell suspension cultures presented in this study, has rarely been reported (Christiernin et al. 2005; Novo-Uzal et al. 2009; Shen et al. 2013).

In addition to its roles in cell wall stiffening, lignin deposition has long been implicated as an important defense mechanism against pests and pathogens Q4 (Vance 1980; Barros-Rios et al. 2011). Lignin or lignin-like polymers are induced and rapidly deposited in cell walls in response to both biotic and abiotic stresses (Moura et al. 2010; Sattler and Funnell-Harris 2013; Miedes et al. 2014). Two types of lignin can be distinguished: (i) the one normally present in secondarily thickened cell walls with a purely structural role, and (ii) ectopic lignin, unexpectedly deposited in response to biotic and abiotic stresses. Lignin composition is highly heterogeneous and phylogenetically dependent, but also depends on the role the lignin is expected to play. 'Defense' lignin is often associated with elevated levels of $\mathrm{H}$ subunits compared with structural lignin (Ride 1975; Lange et al. 1995; Sattler and Funnell-Harris 2013). Although $\mathrm{H}$ units were not present in our system (minor component in monocot lignin; Boerjan et al. 2003), given the phloroglucinol-tonality and compositional differences between SNH+DCB (pink/indicative of a predominance of $\mathrm{S}$ units) and the $\mathrm{SH} 6$ (brown/S+G units) ligninlike polymers, we propose that these polymers could arise from different stimuli. While short-term DCB-treated cells might produce a sensu stricto stress-related lignin, habituated cells might accumulate a structural-related lignin. In accordance with this, $S$ to $G$ ratio estimated for the ligninlike polymer found in DCB-habituated cells (1.5) is close to that of lignin from maize stems (1.4) (Fornalé et al. 2012).

By catalyzing the final hydroxyl-cinnamaldehyde reduction to the corresponding alcohols, CAD is a key enzyme in determining lignin content and composition (Mansell et al. 1974; Fornalé et al. 2012). Although several CAD isoforms (1, 5, 6 and 7) were overexpressed in $\mathrm{SH} 1$ cells, CAD activity was found unchanged. Therefore, it could be assumed for this cell line that higher proportions of the cinnamaldehyde moieties are incorporated into the phenolic polymers, as occurs in CADtransgenic and mutant plants (Ralph et al. 2001; Dauwe et al. 2007; Fornalé et al. 2012). However, CAD activity was found to be approximately three to four times enhanced for $\mathrm{SNH}+\mathrm{DCB}$ and $\mathrm{SH} 6$ cells, respectively, compared to SNH. The increased
CAD activity in SNH+DCB cells correlated with the overexpression of several $C A D$ isoforms (1, 5, 6 and 7), and since only $S$ units were found in measurable amounts in their cell walls, these proteins are most probably involved in the sinapaldehyde conversion to sinapyl alcohol. All of these isoforms were also overexpressed in SH6 cells. As a differential result, habituated cells showed a high overexpression of $C A D 2$, which could be responsible for the synthesis of coniferyl alcohol from coniferaldehyde. In view of these results, we propose ZmCAD2 as a candidate for the production of $\mathrm{G}$ units, at least in the case of maize cell cultures, as well as a key player in the production of lignin-like polymers in $\mathrm{SH} 6$ cells. Interestingly, $C A D 2$ has been specifically associated with the synthesis of structural lignin in maize plants (Fornale et al. 2012), which would agree with the synthesis of a structural related lignin in SH6 cells.

Concerning the two steps prior to CAD, different expression patterns were found in each case. CCR isoforms are responsible for the reduction of $p$-coumaroyl-CoA and feruloyl-CoA to their respective aldehydes. Downregulation of CCR in transgenic poplar has been associated with an up to $50 \%$ reduction in lignin content and an increased proportion of cellulose (Leplé et al. 2007). Interestingly, in contrast to these poplar trees, DCB-habituated cells with the opposite situation for the load-bearing polymers (less cellulose and more lignin) showed a significant overexpression of both $C C R$ isoforms. On the other hand, and also in poplar, upregulation of $\mathrm{F}_{5} \mathrm{H}$ increased the proportion of $\mathrm{S}$ units, yielding an $\mathrm{S} / \mathrm{G}$ ratio of greater than 35 versus approximately 2 for wild type poplar lignin (Stewart et al. 2009). Both $\mathrm{F}_{5} \mathrm{H}$ isoforms were overexpressed in $\mathrm{SH} 1$ cells, where only $S$ units could be detected, while one of them was highly downregulated for SH6 cells. In summary, rather than a general stress response, a tight regulation of the monolignol biosynthetic pathway was observed in DCBhabituated cells.

Lignin polymerization is preceded by the peroxidase $+\mathrm{H}_{2} \mathrm{O}_{2}$ (and/or lacasse $+\mathrm{O}_{2}$ ) dependent activation of monolignols to free radicals (Fagerstedt et al. 2010). The spent cell culture medium can be regarded as an extension of the apoplast and it can therefore be used as a compartment to monitor changes in the level of cell wall $\mathrm{H}_{2} \mathrm{O}_{2}$ (Kärkönen and Kuchitsu 2014). The $\mathrm{H}_{2} \mathrm{O}_{2}$ over-production of $\mathrm{SNH}+\mathrm{DCB}$ and $\mathrm{SH}$ cells may be explained in the context of a reactive oxygen species over-production following cellulose inhibition, as has been previously reported for Arabidopsis plants (Dennes et al. 2011) and maize cultured cells habituated to low DCB concentrations ( $A$ Largo unpublished data). Given the steep increase in lignin over the course of DCB habituation, a relationship between lignin accumulation and increased apoplastic $\mathrm{H}_{2} \mathrm{O}_{2}$ contents may be expected (Nose et al. 1995; Kärkönen et al. 2002). However, no differences in apoplastic $\mathrm{H}_{2} \mathrm{O}_{2}$ were found when $\mathrm{SH} 1$ and $\mathrm{SH} 6$ cells were compared, indicating that $\mathrm{H}_{2} \mathrm{O}_{2}$ is not a limiting factor in the ectopic lignification reported in this system. An alternative explanation would be that the lignification is consuming apoplastic $\mathrm{H}_{2} \mathrm{O}_{2}$ explaining the lower level of apoplastic $\mathrm{H}_{2} \mathrm{O}_{2}$ measured in $\mathrm{SH} 6$ cells when compared with $\mathrm{SH} 1$ or $\mathrm{SNH}+\mathrm{DCB}$ ones. Moreover, a study of class III peroxidase activity did not show differences due to DCB habituation in maize cultured cells (data not shown). 
There are several lines of evidence that link ectopic lignification in response to cellulose deficiency with JA signaling. Constitutive expression of vegetative storage protein 1 (cev1) and ectopic lignin 1 (eli1-1) Arabidopsis mutants, are defective in the cellulose synthase gene CESA3 involved in cellulose biosynthesis during primary cell wall formation (Ellis and Turner 2001; Ellis et al. 2002; Caño-Delgado et al. 2003). In these mutants, cellulose biosynthesis impairment was compensated by mechanisms such as ectopic lignification, constitutive activation of the JA signaling pathway, and increases in JA and ethylene proportions. In addition, treatments with the cellulose biosynthesis inhibitor isoxaben have been found to phenocopy eli1-1 lignification in Arabidopsis wild type seedlings (Caño-Delgado et al. 2003; Hamann et al. 2009). In JA-insensitive plants, ectopic lignification by isoxaben is reduced, indicating that JA signaling is necessary (Caño-Delgado et al. 2003), a deduction which is further confirmed by the finding that external addition of methyl jasmonate to Arabidopsis cell cultures led to increased expression of phenylpropanoid, particularly monolignol biosynthesis (Pauwels et al. 2008). Our results confirm a JA-dependent signaling process in response to cellulose biosynthesis impairment, which led to ectopic lignification. However, according to our RT-PCR results and previous data from proteomic approaches (Mélida et al. 2010a; M de Castro unpublished data), stimulation of the lignification mechanism seems to be SA- and ethyleneindependent.

In summary, maize suspension-cultured cells with up to $70 \%$ less cellulose produced a more extensive and crosslinked network of arabinoxylans together with a polymeric lignin-like material. This modified cell wall architecture is the result of the high structural plasticity of plant primary cell walls in response to a disruption of cell wall integrity. We propose that a JA signaling program might be triggering the observed ectopic lignification, and this model system will be used in future research in order to study the complex networks involved in cell wall integrity maintenance mechanisms.

\section{MATERIALS AND METHODS}

\section{Plant material and DCB habituation process}

Maize callus-cultured cells (Zea mays L. Black Mexican sweetcorn) were obtained from immature embryos and maintained in Murashige and Skoog media (Murashige and Skoog 1962) supplemented with $9 \mu \mathrm{M} 2,4-\mathrm{D}, 20 \mathrm{~g} \mathrm{~L}^{-1}$ sucrose and $8 \%$ agar at $25^{\circ} \mathrm{C}$ under photoperiodic conditions (16:8; 3,000 lux $\approx 41 \mu \mathrm{mol} \mathrm{m} \mathrm{m}^{-2} \mathrm{~s}^{-1}$ ). Callus-cultured cells were habituated to grow under originally lethal DCB concentrations, by stepwise transfers to higher DCB levels up to a $12 \mu \mathrm{M}$ concentration (Mélida et al. 2009). Those cells growing on solid medium were disaggregated and transferred to a liquid medium containing $6 \mu \mathrm{M} \mathrm{DCB}$ (SH6) (Mélida et al. 2011). SH6 cells were maintained at $25^{\circ} \mathrm{C}$ under light, rotary shaken and routinely subcultured every 15 days. Control cells were designated as non-habituated maize suspensioncultured cells $(\mathrm{SNH})$. Cell lines habituated to grow under $1 \mu \mathrm{M}$ DCB (SH1) were obtained from SNH (de Castro et al. 2014).
In order to distinguish toxic DCB effects from those owing to the habituation, short-term treatments with high (lethal) DCB concentrations were performed. Maize control cells were grown in a liquid medium containing $6 \mu \mathrm{M}$ DCB for 6 days, ensuring a toxic effect but not giving sufficient time to kill the cells ( $\mathrm{H}$ Mélida unpublished data). These cells were referred to as $\mathrm{SNH}+\mathrm{DCB}$.

\section{Cell wall preparation and fractionation}

Cell walls were prepared according to Mélida et al. (2009). Briefly, cells were collected during their exponential growth phase, washed extensively with distilled water and immediately frozen. The cells were disrupted in liquid nitrogen using a mortar and pestle. The resulting fine powders were subjected to extraction in $70 \%(\mathrm{v} / \mathrm{v})$ ethanol for 5 days. The suspensions were filtered through glass-fiber filters (GF/A, Whatman ${ }^{\mathrm{Q} 5}$ ), and the pellets were washed six times with $70 \%$ ethanol and six times with acetone and were subsequently air dried, to obtain the alcohol insoluble residue. These were then resuspended in $90 \%$ dimethylsulphoxide for $8 \mathrm{~h}$ three times, filtered as above, washed twice with $0.01 \mathrm{M}$ phosphate buffer $\mathrm{pH} 7.0$ and incubated with $2.5 \mathrm{U} \mathrm{mL}^{-1}$ of $\alpha$-amylase type VI-A dissolved in the same buffer for $24 \mathrm{~h}$ at $37^{\circ} \mathrm{C}$. The suspensions were filtered again and washed with ethanol and acetone as indicated above. The dry pellets were treated with phenol:acetic acid:water $(2: 1: 1, v / v / v)$ for two periods of $8 \mathrm{~h}$, then washed and air dried. The final dry pellets were considered the cell wall extracts.

Cell wall fractions were obtained by consecutively treating the cell wall residues with $\mathrm{KOH}$ solutions according to Mélida et al. (2009). Cell walls were extracted at room temperature with $50 \mathrm{mM}$ trans-1,2-Diaminocyclohexane- $N, N, N^{\prime}, N^{\prime}$ tetraacetic acid (CDTA) at $\mathrm{pH} 6.5$ for $8 \mathrm{~h}$ and washed with distilled water. The residue was then incubated with $0.1 \mathrm{M}$ $\mathrm{KOH}+20 \mathrm{mM} \mathrm{NaBH}_{4}$ for $2 \mathrm{~h}(\times 2)$ and washed with distilled water. Then $4 \mathrm{M} \mathrm{KOH}+20 \mathrm{mM} \mathrm{NaBH}_{4}$ was added to the residue for $4 \mathrm{~h}(\times 2)$, and washed again with distilled water. The extracts were acidified to $\mathrm{pH} 5.0$ with acetic acid, dialyzed and freeze-dried, representing CDTA, KI and KII fractions, respectively. The residue after $4 \mathrm{M} \mathrm{KOH}$ extraction was hydrolyzed with $2 \mathrm{M}$ trifluoroacetic acid (TFA) for $2.5 \mathrm{~h}$ at $120^{\circ} \mathrm{C}$, and after centrifugation, the supernatant was lyophilized and referred to as the TFA fraction.

\section{Cell wall analysis}

Tablets for Fourier transform infrared (FTIR) spectroscopy were prepared in a GrasebySpecac press from small samples ( $2 \mathrm{mg}$ ) of cell walls mixed with $\operatorname{KBr}(1: 100, w / w)$. Spectra were obtained on a Perkin Elmer Spectrum 2000 instrument at a resolution of $1 \mathrm{~cm}^{-1}$. A window between 800 and $1,800 \mathrm{~cm}^{-1}$, which contains information of characteristic polysaccharides, was selected in order to monitor cell wall structure modifications. All spectra were normalized and baseline corrected with Spectrum software (v5.3.1). Then, data were exported to Microsoft Excel 2010 and all spectra were areanormalized.

Cellulose was quantified in crude cell walls by the Updegraff method as described by Encina et al. (2002). Total sugar quantification of cell wall fractions was performed by the phenol-sulphuric acid method $\underline{\text { Q6 }}$ (Dubois et al. 1956) and results were expressed as glucose equivalents. The uronic acid 
sugars were quantified by the m-hydroxydiphenyl method described by Blumenkrantz and Asboe-Hansen (1973) using galacturonic acid as reference standard.

For the analysis of neutral sugars, freeze-dried cell wall fractions were hydrolyzed with $2 \mathrm{M} \mathrm{TFA}$ at $121 \mathrm{~b}^{\circ} \mathrm{C}$ for $1 \mathrm{~h}$. Myoinositol was used as an internal standard. The resulting monosaccharides were converted to alditol acetates as described previously Q7 (Albersheim et al. 1967) and analyzed by gas chromatography (GC) on a SP-2380 capillary column (30 $\mathrm{m} \times 0.25 \mathrm{~mm}$ i.d.; Supelco) using a Perkin Elmer Autosystem.

Ferulate and p-coumarate monomers and esterbound diferulates were extracted at room temperature from $50 \mathrm{mg}$ of the alcohol-insoluble residues (AIR) using $2 \mathrm{M}$ $\mathrm{NaOH}$ for $4 \mathrm{~h}$ and analyzed by high performance liquid chromatography (HPLC) based on a method previously described by Santiago et al. (2006). Retention time and UV spectrum of $5,5^{\prime}$-DFA were compared with freshly prepared external standard solutions of $5,5^{\prime}$-DFA, kindly provided by Dr. John Ralph's group (Department of Biochemistry, University of Wisconsin, Madison, USA). The UV absorption spectra of other DFAs were compared with previously published spectra (Waldron et al. 1996) and absorbance at $325 \mathrm{~nm}$ was used for quantification. Total ester-linkedDFAs concentration was calculated as the sum of three isomers of DFA identified and quantified by this analytical procedure: 8,5'-DFA, 8-O-4'-DFA, and 5,5'-DFA. The 8,5'DFA concentration was calculated as the sum of the $8,5^{\prime}$-noncyclic (or open)-DFA and 8,5'-cyclic (or benzofuran)DFA because the non-cyclic form is most likely formed during alkaline hydrolysis from the native cyclic form (Ralph et al. 1994b).

Lignin-like material was quantified by the Klason gravimetric method with minor modifications. Cell wall extracts were hydrolyzed with $72 \%(\mathrm{w} / \mathrm{v})$ sulfuric acid for $1 \mathrm{~h}$ at $30^{\circ} \mathrm{C}$. Then, the sulfuric acid concentration was diluted to $2.5 \%(\mathrm{w} / \mathrm{v})$ with water and further incubated at $115^{\circ} \mathrm{C}$ for $1 \mathrm{~h}$. The residues were filtrated through Durapore polyvinylidene fluoride (PVDF) filters (Millipore $\stackrel{\mathrm{Q} 8}{-} 0.45 \mu \mathrm{m}$ ), dried and weighed.

Thioacidolysis of cell walls, which solubilizes the $\beta-O$ 4lignin core, and GC-MS analyses were performed (NovoUzal et al. 2009) using a Thermo Finnigan Q9 Trace GC gas chromatograph, a Thermo Finnigan Polaris Q mass spectrometer, and a DB-XLB, J\&W (60 $\mathrm{m} \times 0.25 \mathrm{~mm}$ I.D. $)$ column.

\section{Histochemical staining of cinnamyl-aldehydes}

Intact filtered maize cells were incubated with $1 \%(\mathrm{w} / \mathrm{v})$ phloroglucinol in $70 \%(\mathrm{v} / \mathrm{v})$ ethanol for $5 \mathrm{~min}$. Then, the phloroglucinol solution was removed and the cells were further incubated with an $18 \%(\mathrm{w} / \mathrm{v}) \mathrm{HCl}$ solution. Stained cells were observed under Nikon SMZ1500 magnifier and photographed using a Nikon Digital Camera DXM1200F.

\section{Relative gene expression analysis}

DCB-habituated cells ( $\mathrm{SH} 1$ and $\mathrm{SH} 6$ ) were collected during their respective exponential growth phases and a set of $\mathrm{SNH}$ cells were collected at the same time for comparison. In the case of short-term DCB treatments, SNH+DCB cells and a set of SNH cells were collected on the third day of culture. Total RNA was extracted from homogenized cells of all lines following the procedures established for Trizol reagent
(Invitrogen ${ }^{\mathrm{Q} 10}$ ). The purity and integrity of the extracted RNA was evaluated spectrophotometrically using a Nanodrop 1000 and running the RNA in $1 \%$ agarose gels. RNA ( $2 \mu \mathrm{g})$ was reverse-transcribed with Super Script III First strand retrotranscriptase (Invitrogen) using oligo $(\mathrm{dT})_{20}$ as primer. The synthesized cDNA was used to perform the gene expression analyses by standard and quantitative PCR methods.

Semiquantitative expression analysis by RT-PCR was performed for jasmonic (JA) and salicylic acid (SA) signaling pathway genes: 12-oxophytodienoatereductase (ZmOPR1, AY921638; ZmOPR2, AY921639 and ZmOPR7, AY921644), NADPH oxidase (ZmNADPHOX, CK849936), maize protease inhibitor (ZmMPI, X78988), pathogenesis related protein 1 (ZmPR1, UB2200) and non-expressor of PR1 (ZmNPR1, EU95584). Primers can be found in Supplemental Table S1. The ubiquitin gene was used as a reference gene for this experiment (ZmUBI, U29159) (Fornalé et al. 2006).

Reverse transcription-PCR agarose gels were stained with SYBR Safe DNA gel stain (Invitrogen) and gel images acquired with an Alphaimager HP system (ProteinSimple $\stackrel{\mathrm{Q}^{11}}{ }$ ). The quantification of the bands was performed by using the Alpha view v3.4.0.0. software (ProteinSimple). Band intensity was expressed as relative intensity units. For each individual gene, the band intensity was normalized in relation to ubiquitin and then, the normalized intensity ratios for $\mathrm{SNH}+\mathrm{DCB} / \mathrm{SNH} ; \mathrm{SH}_{1} / \mathrm{SNH}$ and $\mathrm{SH} 6 / \mathrm{SNH}$ were calculated.

Relative gene expression was determined by qRT$P C R$ using specific primers for the following genes: ferulate 5-hydroxylase $\quad\left[\mathrm{ZmF}_{5} \mathrm{H}_{1} \quad\left(\mathrm{AC}_{210173.4)}\right.\right.$ and $\mathrm{ZmF}_{5} \mathrm{H}_{2}$ (GRMZM2G100158)], cinnamoyl-CoA reductase [ZmCCR1 (GRMZM2G131205) and ZmCCR2 (GRMZM2G131836)] and cinnamyl alcohol dehydrogenase [ZmCAD1 (Y13733; GRMZM5G844562), ZmCAD2 (GRMZM2G118610), ZmCAD3 (GRMZM2G046070), ZmCAD4 (GRMZM2G700188), ZmCAD5 (GRMZM2G443445), ZmCAD6 (GRMZM2G090980) and ZmCAD7 (GRMZM167613)] as described by Guillaumie et al. (2007). Folylpolyglutamate synthase (ZmFPGS; GRMZM2G393334) and the Ubiquitin carrier protein (ZmUBCP; GRMZM2G102471) genes were used as reference genes (Manoli et al. 2012). Primers can be found in Supplemental Table S1.

The $\mathrm{qPCR}$ was carried out in a StepOnePlus platform (Applied Biosystems $\_$12) using Power SYBR green PCR master mix (Applied Biosystems), $2 \mu \mathrm{L}$ of each CDNA concentration (50 and $100 \mathrm{ng} \mu \mathrm{L}^{-1}$ ) and a mix of both primers at $10 \mu \mathrm{M}$. All samples were run in triplicate with the following temperature profile: initial denaturation at $95^{\circ} \mathrm{C}$ for $10 \mathrm{~min}$, followed by 40 cycles of $95^{\circ} \mathrm{C}$ for $10 \mathrm{~s}$ and $60^{\circ} \mathrm{C}$ for $1 \mathrm{~min}$ (annealing and elongation). The relative gene expression was calculated by ' $\delta$ - $\delta$ ' method (Livak and Schmittgen 2001) implemented in the StepOne Software v2.2.2. A no-template negative control and a melting curve were performed in each sample set to control the primer dimers and contaminants in the reactions.

\section{CAD enzyme activity assay}

$C A D$ enzyme activity was measured by following the method described by Chabannes et al. (2001) modified by Fornalé et al. (2012). Fresh cells were homogenized under liquid nitrogen with a mortar and pestle until a fine powder was obtained, and $5 \mathrm{~mL}$ of extraction buffer (100 mM Tris- $\mathrm{HCl} \mathrm{pH} \mathrm{7.5,} \mathrm{2 \%} \mathrm{(w/v)} \mathrm{PEG}$ $6000,5 \mathrm{mM}$ DTT and $2 \%(\mathrm{w} / \mathrm{v})$ PPVP) were added. The 
suspension was centrifuged at $10,000 \mathrm{~g}$ for $10 \mathrm{~min}$ at $4{ }^{\circ} \mathrm{C}$ and the supernatant was collected. The centrifugation process was repeated until the supernatant was clear.

CAD activity assays were carried out by measuring the absorbance increment at $400 \mathrm{~nm}$ when coniferyl alcohol was oxidized to coniferyl aldehyde. The reactions were performed in 96-well plates containing $140 \mu \mathrm{L}$ of $140 \mathrm{mM}$ Tris- $\mathrm{HCl} \mathrm{pH} \mathrm{8.8,}$ $20 \mu \mathrm{L}$ of $1 \mathrm{mM}$ coniferyl alcohol, $20 \mu \mathrm{L}$ of $200 \mu \mathrm{M} \mathrm{NADP}{ }^{+}$and $20 \mu \mathrm{L}$ of sample. The mixtures were mixed and incubated at $30^{\circ} \mathrm{C}$ for $10 \mathrm{~min}$, and the reactions were measured over the following $10 \mathrm{~min}$ in a plate reader Synergy HT (Bio-Teck $\stackrel{\mathrm{Q} 13}{ }$ ) at $30^{\circ} \mathrm{C}$. Reaction and sample blanks were routinely used.

\section{Apoplastic $\mathrm{H}_{2} \mathrm{O}_{2}$ content determination}

Apoplastic $\mathrm{H}_{2} \mathrm{O}_{2}$ content was determined with the xylenol orange method as described by Bindschedler et al. (2001). For the reactions, $150 \mu \mathrm{L}$ of culture media was mixed with $1 \mathrm{~mL}$ of reaction mixture $(125 \mu \mathrm{M}$ xylenol orange, $100 \mathrm{mM}$ D-sorbitol,

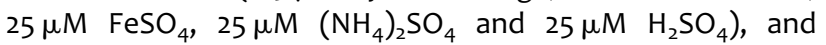
absorbance $(560 \mathrm{~nm})$ was measured after $40 \mathrm{~min}$ of incubation.

\section{ACKNOWLEDGEMENTS}

This work was supported by grants from the Ministry of Economy and Competitiveness (Spain) (AGL2011-30545-C02-2 to $A E$; JdC to ENU; Ramón y Cajal to RS). HM was supported by funds from the European Commission (IEF-SignWALLINg624721). ALG hold a predoctoral grant from the University of León. We gratefully acknowledge Professor Stephen C. Fry (University of Edinburgh) for his kind provision of maize cell cultures and Denise Phelps for the English revision of the manuscript.

\section{REFERENCES}

Albersheim P, Nevins PD, English PD, Karr A (1967) A method for the analysis of sugars in plant cell wall polysaccharides by gas liquid chromatography. Carbohydr Res 5: 340-345

Alonso-Simón A, García-Angulo P, Mélida H, Encina A, Álvarez JM, Acebes JL (2011) The use of FTIR spectroscopy to monitor modifications in plant cell wall architecture caused by cellulose biosynthesis inhibitors. Plant Signal Behav 6: 1104-1110

Ambavaram MM, Krishnan A, Trijatmiko KR, Pereira A (2011) Coordinated activation of cellulose and repression of lignin biosynthesis pathways in rice. Plant Physiol 155: 916-931

Barros-Rios J, Malvar RA, Jung HJ, Santiago R (2011) Cell wall composition as a maize defense mechanism against corn borers. Phytochemistry 72: 365-371

Bindschedler LV, Minibayeva F, Gardner SL, Gerrish C, Davies DR, Bolwell GP (2001) Early signalling events in the apoplastic oxidative burst in suspension cultured French bean cells involve CAMP and $\mathrm{Ca}^{2+}$. New Phytol 151: 185-194

Bischoff V, Cookson SJ, Wu S, Scheible WR (2009) Thaxtomin A affects CESA-complex density, expression of cell wall genes, cell wall composition, and causes ectopic lignification in Arabidopsis thaliana seedlings. J Exp Bot 60: 955-965

Blumenkrantz N, Asboe-Hansen G (1973) New method for quantitative determination of uronic acids. Anal Biochem 54: 484-489
Boerjan W, Ralph J, Baucher M (2003) Lignin biosynthesis. Annu Rev Plant Biol 54: 519-546

Brabham C, Lei L, Gu Y, Stork J, Barrett M, DeBolt S (2014) Indaziflam herbicidal action: A potent cellulose biosynthesis inhibitor. Plant Physiol 166: 1177-1185

Brochu V, Girard-Martel M, Duval I, Lerat S, Grondin G, Domingue O, Beaulieu C, Beaudoin N (2010) Habituation to thaxtomin A in hybrid poplar cell suspensions provides enhanced and durable resistance to inhibitors of cellulose synthesis. BMC Plant Biol 10: 272

Buanafina MM (2009) Feruloylation in grasses: Current and future perspectives. Mol Plant 2: 861-872

Caño-Delgado Al, Metzlaff K, Bevan MW (2000) The eli1 mutation reveals a link between cell expansion and secondary cell wall formation in Arabidopsis thaliana. Development 127: 3395-3405

Caño-Delgado A, Penfield S, Smith C, Catley M, Bevan M (2003) Reduced cellulose synthesis invokes lignification and defense responses in Arabidopsis thaliana. Plant J 34: 351-362

Carpita NC (1996) Structure and biogenesis of the cell walls of grasses. Annu Rev Plant Physiol Plant Mol Biol 47: 445-476

de Castro M, Largo-Gosens A, Alvarez JM, García-Angulo P, Acebes JL (2014) Early cell-wall modifications of maize cell cultures during habituation to dichlobenil. J Plant Physiol 171: 127-135

de Castro M, Miller JG, Acebes JL, Encina A, García-Angulo P, Fry SC (2015) The biosynthesis and wall-binding of hemicelluloses in cellulose-deficient maize plasticity. J Integr Plant Biol 57: doi: 10.1111/jipb.12331

Chabannes M, Barakate A, Lapierre C, Marita JM, Ralph J, Pean M, Danoun S, Halpin C, Grima-Pettenati J, Boudet AM (2001). Strong decrease in lignin content without significant alteration of plant development is induced by simultaneous down-regulation of cinnamoyl CoA reductase (CCR) and cinnamyl alcohol dehydrogenase (CAD) in tobacco plants. Plant J 28: 257-270

Christiernin M, Ohlsson AB, Berglund T, Henriksson G (2005) Lignin isolated from primary walls of hybrid aspen cell cultures indicates significant differences in lignin structure between primary and secondary cell wall. Plant Physiol Biochem 43: 777-785

Dauwe R, Morreel K, Goeminne G, Gielen B, Rohde A, Van Beeumen J, Ralph J, Boudet AM, Kopka J, Rochange SF, Halpin C, Messens E, Boerjan W (2007) Molecular phenotyping of ligninmodified tobacco reveals associated changes in cellwall metabolism, primary metabolism, stress metabolism and photorespiration. Plant J 52: 263-285

Denness L, McKenna JF, Segonzac C, Wormit A, Madhou P, Bennett M, Mansfield J, Zipfel C, Hamann T (2011) Cell wall damageinduced lignin biosynthesis is regulated by a reactive oxygen species- and jasmonic acid-dependent process in Arabidopsis. Plant Physiol 156: 1364-1374

Desprez T, Vernhettes S, Fagard M, Refrégier G, Desnos T, Aletti E, Py $\mathrm{N}$, Pelletier S, Höfte H (2002) Resistance against herbicide isoxaben and cellulose deficiency caused by distinct mutations in same cellulose synthase isoform CESA6. Plant Physiol 128: 482-490

Dubois M, Gilles KO, Hamilton JK, Rebers PA, Smith F (1956) Colorimetric method for determination of sugars and related substances. Anal Chem 28: 350-356

Ellis C, Karafyllidis I, Wasternack C, Turner JG (2002) The Arabidopsis mutant cev1 links cell wall signaling to jasmonate and ethylene responses. Plant Cell 14: 1557-1566

Ellis C, Turner JG (2001) The Arabidopsis mutant cev1 has constitutively active jasmonate and ethylene signal pathways and enhanced resistance to pathogens. Plant Cell 13: 1025-1033 
Encina A, Sevillano JM, Acebes JL, Alvarez J (2002) Cell wall modifications of bean (Phaseolus vulgaris) cell suspensions during habituation and dehabituation to dichlobenil. Physiol Plant 114: 182-191

Fincher GB (2009) Revolutionary times in our understanding of cell wall biosynthesis and remodeling in the grasses. Plant Physiol 149: $27-37$

Fukuda H, Komamine A (1980) Establishment of an experimental system for the study of tracheary element differentiation from single cells isolated from the mesophyll of Zinnia elegans. Plant Physiol 65: 57-60

Fornalé S, Capellades M, Encina A, Wang K, Irar S, Lapierre C, Ruel K, Joseleau JP, Berenguer J, Puigdomènech P, Rigau J, CaparrósRuiz D (2012) Altered lignin biosynthesis improves cellulosic bioethanol production in transgenic maize plants downregulated for cinnamyl alcohol dehydrogenase. Mol Plant 5: $817-830$

Fornalé S, Sonbol FM, Maes T, Capellades M, Puigdomenech P, Rigau J, Caparrós-Ruiz D (2006) Down-regulation of the maize and Arabidopsis thaliana caffeic acid O-methyl-transferase genes by two new maize R2R3-MYB transcription factors. Plant Mol Biol 62: 809-823

García-Angulo P, Alonso-Simón A, Mélida H, Encina A, Acebes JL, Alvarez JM (2009) High peroxidase activity and stable changes in the cell wall are related to dichlobenil tolerance. J Plant Physiol 166: $1229-1240$

Guerriero G, Fugelstad J, Bulone V (2010) What do we really know about cellulose biosynthesis in higher plants? J Integr Plant Biol 52: $161-175$

Guillaumie S, San-Clemente H, Deswarte C, Martinez Y, Lapierre C, Murigneux $A$, Barrière $Y$, Pichon $M$, Goffner $D$ (2007) MAIZEWALL: Database and developmental gene expression profiling of cell wall biosynthesis and assembly in maize. Plant Physiol 143: 339-363

Hamann T (2014) The plant cell wall integrity maintenance mechanism 15 -Concepts for organization and mode of action. Plant Cell Physiol in press doi: 10.1093/pcp/pcu164

Hamann T, Bennett M, Mansfield J, Somerville C (2009) Identification of cell-wall stress as a hexose-dependent and osmosensitive regulator of plant responses. Plant J 57: 1015-1026

Hatfield RD, Marita JM (2010) Enzymatic processes involved in the incorporation of hydroxycinnamates into grass cell walls. Phytochem Rev 9: 35-45

Hernández-Blanco C, Feng DX, Hu J, Sánchez-Vallet A, Deslandes L, Llorente $F$, Berrocal-Lobo $M$, Keller $H$, Barlet $X$, SánchezRodríguez C, Anderson LK, Somerville S, Marco Y, Molina A (2007) Impairment of cellulose synthases required for Arabidopsis secondary cell wall formation enhances disease resistance. Plant Cell 19: 890-903

liyama K, Lam T, Stone BA (1994) Covalent cross-links in the cell wall. Plant Physiol 104: 315-320

Jarvis MC (2013) Cellulose biosynthesis: Counting the chains. Plant Physiol 163: 1485-1486

Kačuráková M, Capek P, Sasinková V, Wellner N, Ebringerová A (2000) FT-IR study of plant cell wall model compounds: pectic polysaccharides and hemicelluloses. Carbohydr Polym 43: 195-203

Kärkönen A, Koutaniemi S (2010) Lignin biosynthesis studies in plant tissue cultures. J Integr Plant Biol 52: 176-185

Kärkönen A, Koutaniemi S, Mustonen $M$, Syrjänen $K$, Brunow $G$, Kilpeläinen I, Teeri TH, Simola LK (2002) Lignification related enzymes in Picea abies suspension cultures. Physiol Plant 114: 343-353
Kärkönen A, Kuchitsu K (2014) Reactive oxygen species in cell wall metabolism $\mathrm{Q}^{\mathrm{Q} 16}$ and development in plants. Phytochemistry in press doi: 10.1016/j.phytochem.2014.09.016

Kärkönen A, Warinowski T, Teeri TH, Simola LK, Fry SC (2009) On the mechanism of apoplastic $\mathrm{H}_{2} \mathrm{O}_{2}$ production during lignin formation and elicitation in cultured spruce cells-peroxidases after elicitation. Planta 230: 553-567

Fagerstedt KV, Kukkola EM, Koistinen VVT, Takahashi J, Marjama K (2010) Cell wall lignin is polymerised by class III secretable plant peroxidases in Norway Spruce. J Integr Plant Biol 52: 186-194

Lange BM, Lapierre C, Sandermann H Jr. (1995) Elicitor-induced spruce stress lignin (structural similarity to early developmental lignins). Plant Physiol 108: 1277-1287

Largo-Gosens A, Hernández-Altamirano M, García-Calvo L, AlonsoSimón A, Álvarez J, José L. Acebes (2014) Fourier transform mid infrared spectroscopy applications for monitoring the structural plasticity of plant cell walls. Front Plant Sci 5: 303. doi: 10.3389/ fpls.2014.00303

Leplé JC, Dauwe R, Morreel K, Storme V, Lapierre C, Pollet B, Naumann $A$, Kang KY, Kim $\mathrm{H}$, Ruel K, Lefèbvre $A$, Joseleau JP, GrimaPettenati J, De Rycke R, Andersson-Gunnerås S, Erban A, Fehrle I, Petit-Conil M, Kopka J, Polle A, Messens E, Sundberg B, Mansfield SD, Ralph J, Pilate G, Boerjan W (2007) Downregulation of cinnamoyl-coenzyme A reductase in poplar: multiplelevel phenotyping reveals effects on cell wall polymer metabolism and structure. Plant Cell 19: 3669-3691

Lindsay SE, Fry SC (2008) Control of diferulate formation in dicotyledonous and gramineous cell-suspension cultures. Planta 227: 439-452

Liu CJ (2012) Deciphering the enigma of lignification: Precursor transport, oxidation, and the topochemistry of lignin assembly. Mol Plant 5: 304-317

Livak KJ, Schmittgen TD (2001) Analysis of relative gene expression data using real-time quantitative PCR and the 2(-Delta Delta C(T)) Method. Methods 25: 402-408

Lucas WJ, Groover A, Lichtenberger R, Furuta K, Yadav SR, Helariutta $\mathrm{Y}$, He XQ, Fukuda H, Kang J, Brady SM, Patrick JW, Sperry J, Yoshida A, López-Millán AF, Grusak MA, Kachroo P (2013) The plant vascular system: evolution, development and functions. J Integr Plant Biol 55: 294-388

Manfield IW, Orfila C, McCartney L, Harholt J, Bernal AJ, Scheller HV, Gilmartin PM, Mikkelsen JD, Paul Knox J, Willats WG (2004) Novel cell wall architecture of isoxaben-habituated Arabidopsis suspension-cultured cells: Global transcript profiling and cellular analysis. Plant J 40: 260-275

Manoli A, Sturaro A, Trevisan S, Quaggiotti S, Nonis A (2012) Evaluation of candidate reference genes for qPCR in maize. J Plant Physiol 169: 807-815

Mansell RL, Gross C, Stockigt J, Franke H, Zenk MH (1974) Purification and properties of cinnamyl alcohol dehydrogenase from higher plants involved in lignin biosynthesis. Phytochemistry 13: 2427-2437

Mélida H, Álvarez J, Acebes JL, Encina A, Fry SC (2011) Changes in cinnamic acid derivatives associated with the habituation of maize cells to dichlobenil. Mol Plant 4: 869-878

Mélida H, Encina A, Alvarez J, Acebes JL, Caparrós-Ruiz D (2010a) Unraveling the biochemical and molecular networks involved in maize cell habituation to the cellulose biosynthesis inhibitor dichlobenil. Mol Plant 3: 842-853

Mélida H, García-Angulo P, Alonso-Simón A, Alvarez JM, Acebes JL, Encina A (2010b) The phenolic profile of maize primary cell wall changes in cellulose-deficient cell cultures. Phytochemistry 71: $1684-1689$ 
Mélida H, García-Angulo P, Alonso-Simón A, Encina A, Alvarez J, Acebes JL (2009) Novel type II cell wall architecture in dichlobenilhabituated maize calluses. Planta 229: 617-631

Miedes E, Vanholme R, Boerjan W, Molina A (2014) The role of the secondary cell wall in plant resistance to pathogens. Front Plant Sci 5: 358

Moura JC, Bonine CA, de Oliveira Fernandes Viana J, Dornelas MC, Mazzafera $\mathrm{P}$ (2010) Abiotic and biotic stresses and changes in the lignin content and composition in plants. J Integr Plant Biol 52: 360-376

Murashige T, Skoog F (1962) A revised medium for rapid growth and bio assays with tobacco tissue cultures. Physiol Plant 15: 473-497

Nose M, Bernards MA, Furlan M, Zajicek J, Eberhardt TL, Lewis NG (1995) Towards the specification of consecutive steps in macromolecular lignin assembly. Phytochemistry 39: 71-79

Novo-Uzal E, Gomez Ros LV, Pomar F, Bernal MA, Paradela A, Albar JP, Ros Barcelo A (2009) The presence of sinapyl lignin in Ginkgo biloba cell cultures changes our views of the evolution of lignin biosynthesis. Physiol Plant 135: 196-213

Oda Y, Mimura T, Hasezawa S (2005) Regulation of secondary cell wall development by cortical microtubules during tracheary element differentiation in Arabidopsis cell suspensions. Plant Physiol 137: 1027-1036

Passardi F, Penel C, Dunand C (2004) Performing the paradoxical: How plant peroxidases modify the cell wall. Trends Plant Sci 9: 534-540

Pauwels L, Morreel K, De Witte E, Lammertyn F, Van Montagu M, Boerjan W, Inzé D, Goossens A (2008) Mapping methyl jasmonate-mediated transcriptional reprogramming of metabolism and cell cycle progression in cultured Arabidopsis cells. Proc Natl Acad Sci USA 105: 1380-1385

Pomar F, Merino F, Barceló AR (2002) O-4-Linked coniferyl and sinapyl aldehydes in lignifying cell walls are the main targets of the Wiesner (phloroglucinol- $\mathrm{HCl}$ ) reaction. Protoplasma 220: 17-28

Ralph J, Hatfield RD, Quideau S, Helm RF, Grabber JH, Jung HJG (1994a) Pathway of $p$-coumaric acid incorporation into maize lignin as revealed by NMR. J Am Chem Soc 116: 9448-9456

Ralph J, Quideau S, Grabber JH, Hatfield RD (1994b) Identification and synthesis of new ferulic acid dehydrodimers present in grass cellwalls. J Chem Soc-Perkin Trans 1: 3485-3498

Ralph J, Lapierre C, Marita JM, Kim H, Lu F, Hatfield RD, Ralph S, Chapple C, Franke R, Hemm MR, Van Doorsselaere J, Sederoff RR, O'Malley DM, Scott JT, MacKay JJ, Yahiaoui N, Boudet A, Pean M, Pilate G, Jouanin L, Boerjan W (2001) Elucidation of new structures in lignins of CAD- and COMT-deficient plants by NMR. Phytochemistry 57: 993-1003

Ride JP (1975) Lignification in wounded wheat leaves in response to fungi and its possible rôle in resistance. Physiol Plant Pathol 5: 125-134

Ros Barceló A (1997) Lignification in plant cell walls. Int Rev Cytol 176: $87-132$

Santiago R, Butron A, Arnason JT, Reid LM, Souto XC, Malvar RA (2006) Putative role of pith cell wall phenylpropanoids in Sesamia nonagrioides (Lepidoptera: Noctuidae) resistance. J Agric Food Chem 54: 2274-2279

Sattler SE, Funnell-Harris DL (2013) Modifying lignin to improve bioenergy feedstocks: Strengthening the barrier against pathogens? Front Plant Sci 4: 70
Scheller HV, Ulvskov P (2010) Hemicelluloses. Annu Rev Plant Biol 61: 263-289

Shedletzky E, Shmuel M, Delmer DP, Lamport DT (1990) Adaptation and growth of tomato cells on the herbicide 2,6dichlorobenzonitrile leads to production of unique cell walls virtually lacking a cellulose-xyloglucan network. Plant Physiol 94: 980-987

Shedletzky E, Shmuel M, Trainin T, Kalman S, Delmer D (1992) Cell wall structure in cells adapted to growth on the cellulosesynthesis inhibitor 2,6-Dichlorobenzonitrile: A comparison between two dicotyledonous plants and a graminaceous monocot. Plant Physiol 100: 120-130

Shen $\mathrm{H}$, Mazarei M, Hisano H, Escamilla-Trevino L, Fu C, Pu Y, Rudis MR, Tang $Y$, Xiao X, Jackson L, Li G, Hernandez T, Chen F, Ragauskas AJ, Stewart CN Jr, Wang ZY, Dixon RA (2013) A genomics approach to deciphering lignin biosynthesis in switchgrass. Plant Cell 25: 4342-4361

Shivaji R, Camas A, Ankala A, Engelberth J, Tumlinson JH, Williams WP, Wilkinson JR, Luthe DS (2010) Plants on constant alert: Elevated levels of jasmonic acid and jasmonate-induced transcripts in caterpillar-resistant maize. J Chem Ecol 36: 179-191

Simola LK, Lemmetyinen J, Santanen A (1992) Lignin release and photomixotrophism in suspension cultures of Picea abies. Physiol Plant 84: 374-379

Sonbol FM, Fornalé S, Capellades M, Encina A, Touriño S, Torres JL, Rovira P, Ruel K, Puigdomènech P, Rigau J, Caparrós-Ruiz D (2009) The maize ZmMYB42 represses the phenylpropanoid pathway and affects the cell wall structure, composition and degradability in Arabidopsis thaliana. Plant Mol Biol 70: 283-296

Stewart JJ, Akiyama T, Chapple C, Ralph J, Mansfield SD (2009) The effects on lignin structure of overexpression of ferulate 5hydroxylase in hybrid poplar. Plant Physiol 150: 621-635

Vance CP (1980) Lignification as a mechanism of disease resistance. Annu Rev Phytopathol 18: 259-288

Vanholme R, Demedts B, Morreel K, Ralph J, Boerjan W (2010) Lignin biosynthesis and structure. Plant Physiol 153: 895-905

Waldron KW, Parr AJ, Ng A, Ralph J (1996) Cell wall esterified phenolic dimers: Identification and quantification by reverse phase high performance liquid chromatography and diode array detection. Phytochem Anal 7: 305-312

Wallace G, Fry SC (1994) Phenolic components of the plant cell wall. Int Rev Cytol 151: 229-267

\section{SUPPORTING INFORMATION}

Additional supporting information may be found in the online version of this article.

Figure S1. Cell wall fractionation Total sugars in (A) CDTA, (B) $\mathrm{KI},(C) \mathrm{KII}$ and (D) TFA cell wall fraction obtained from $\mathrm{SNH}$, $\mathrm{SNH}+\mathrm{DCB}, \mathrm{SH} 1$ and $\mathrm{SH} 6$ cell lines. For maize cell line annotation see Figure 1 legend. Data represents the means values \pm s.d. of 3 technical replicates. Asterisks indicate values that are significantly different from SNH after a Student's ttest $(\mathrm{P}<0.05)$.

Table S1. Primers used in RT-PCR and RT-qPCR experiments 


\section{JOURNAL: JOURNAL OF INTEGRATIVE PLANT BIOLOGY}

\section{Article: jipb12346}

Dear Author,

During the copyediting of your paper, the following queries arose. Please respond to these by annotating your proofs with the necessary changes/additions using the E-annotation guidelines attached after the last page of this article.

We recommend that you provide additional clarification of answers to queries by entering your answers on the query sheet, in addition to the text mark-up.

\begin{tabular}{|c|c|c|}
\hline Query No. & Query & Remark \\
\hline Q1 & Please provide the significance of dagger in author field. & \\
\hline Q2 & $\begin{array}{l}\text { Ambavaran et al. } 2011 \text { has been changed to Ambavaram et al. } 2011 \text { to } \\
\text { match with reference list. Please check. }\end{array}$ & \\
\hline Q3 & Please check whether " assignations" is correct. & \\
\hline Q4 & Please check the change made in reference Vance, (1980) in text. & \\
\hline Q5 & $\begin{array}{l}\text { Please provide the city, state (if USA) and country of manufacturer: } \\
\text { Whatman. }\end{array}$ & \\
\hline Q6 & $\begin{array}{l}\text { Dubois } 1956 \text { has been changed to Dubois et al. } 1956 \text { to match with } \\
\text { reference list. Please check. }\end{array}$ & \\
\hline Q7 & $\begin{array}{l}\text { Albersheim et al. } 1983 \text { has been changed to Albersheim et al. } 1967 \text { to } \\
\text { match with the reference list. Please check. }\end{array}$ & \\
\hline Q8 & $\begin{array}{l}\text { Please provide the city, state (if USA) and country of manufacturer: } \\
\text { Millipore. }\end{array}$ & \\
\hline Q9 & $\begin{array}{l}\text { Please provide the city, state (if USA) and country of manufacturer: } \\
\text { Thermo Finnigan. }\end{array}$ & \\
\hline Q10 & $\begin{array}{l}\text { Please provide the city, state (if USA) and country of manufacturer: } \\
\text { Invitrogen. }\end{array}$ & \\
\hline Q11 & $\begin{array}{l}\text { Please provide the city, state (if USA) and country of manufacturer: } \\
\text { ProteinSimple. }\end{array}$ & \\
\hline Q12 & $\begin{array}{l}\text { Please provide the city, state (if USA) and country of manufacturer: } \\
\text { Applied Biosystems. }\end{array}$ & \\
\hline Q13 & $\begin{array}{l}\text { Please provide the city, state (if USA) and country of manufacturer: Bio- } \\
\text { Teck. }\end{array}$ & \\
\hline Q14 & Please provide page range for the reference de Castro et al. 2015. & \\
\hline Q15 & Please provide volume and page range for reference Hamann (in press) & \\
\hline Q16 & $\begin{array}{l}\text { Please provide volume and page range for reference Kärkönen and } \\
\text { Kuchitsu (in press). }\end{array}$ & \\
\hline
\end{tabular}


Required software to e-Annotate PDFs: Adobe Acrobat Professional or Adobe Reader (version 8.0 or above). (Note that this document uses screenshots from Adobe Reader $\mathrm{X}$ )

The latest version of Acrobat Reader can be downloaded for free at: http://get.adobe.com/reader/

Once you have Acrobat Reader open on your computer, click on the Comment tab at the right of the toolbar:

닙

This will open up a panel down the right side of the document. The majority of tools you will use for annotating your proof will be in the Annotations section, pictured opposite. We've picked out some of these tools below:

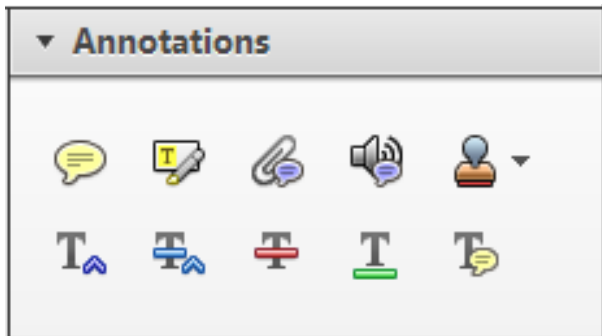

1. Replace (Ins) Tool - for replacing text.

Strikes a line through text and opens up a text box where replacement text can be entered.

\section{How to use it}

- Highlight a word or sentence.

- Click on the Replace (Ins) icon in the Annotations section.

- Type the replacement text into the blue box that appears.

Idard tramework for the analysis of $\mathrm{m}$ icy-Nevertheless, it also led to exog،

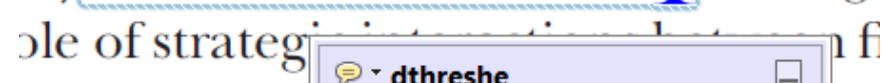
aber of comp 08/06/2011 15:58:17

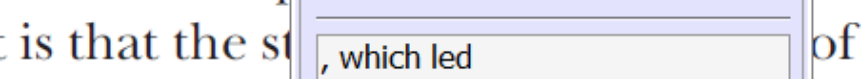
nain compo: be level, are exc nc

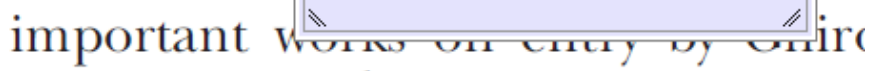
M heneferth) ${ }^{1}$ we anen the 'hlark $\mathrm{h}$

3. Add note to text Tool - for highlighting a section to be changed to bold or italic.

T Highlights text in yellow and opens up a text box where comments can be entered.

\section{How to use it}

- Highlight the relevant section of text.

- Click on the Add note to text icon in the Annotations section.

- Type instruction on what should be changed regarding the text into the yellow box that annears.

namic responses of mark ups ent with the VAR evidence

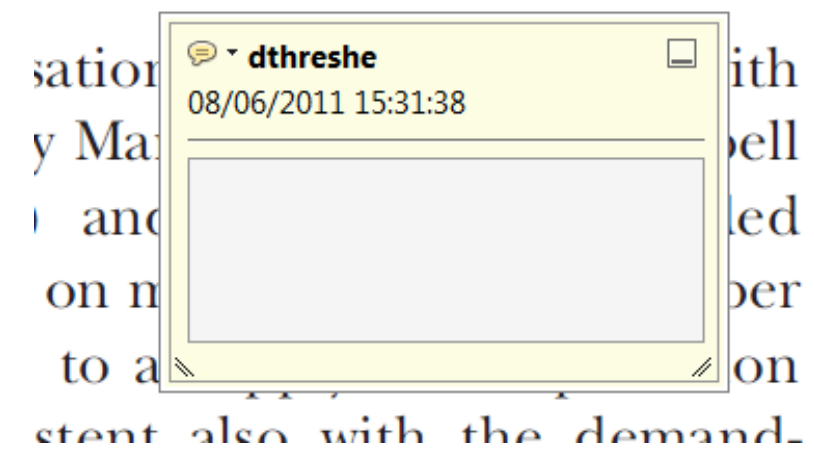

2. Strikethrough (Del) Tool - for deleting text.

Thikes a red line through text that is to be deleted.

\section{How to use it}

- Highlight a word or sentence.

- Click on the Strikethrough (Del) icon in the Annotations section.

there is no room tor extra prohts al c ups are zero and the number of ret) values are not determined by Blanchard and Kiyotaki (1987), rfect competition in general equilil ts of aggregate demand and supply lassical framework assuming monol eon an evorenois number of firms

\section{Add sticky note Tool - for making notes at} specific points in the text.

Marks a point in the proof where a comment needs to be highlighted.

\section{How to use it}

- Click on the Add sticky note icon in the Annotations section.

- Click at the point in the proof where the comment should be inserted.

- Type the comment into the yellow box that appears.

lallu allu suppiy silucks. hivst vi

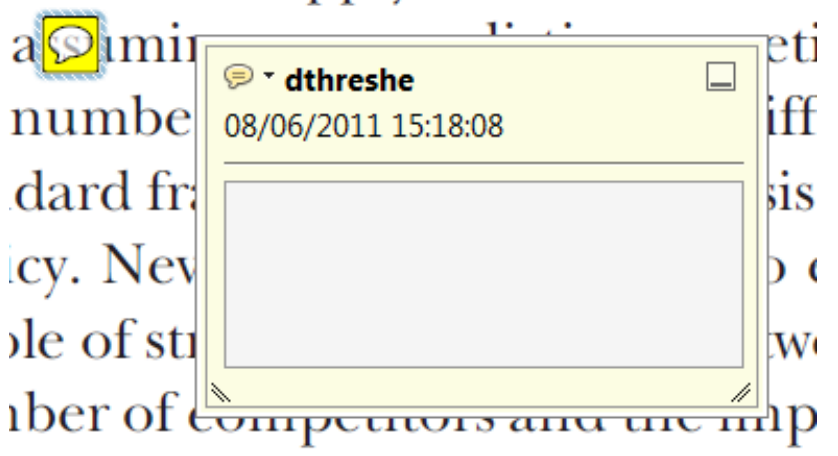

is that the structure of the secto 
5. Attach File Tool - for inserting large amounts of text or replacement figures.

Inserts an icon linking to the attached file in the appropriate pace in the text.

How to use it

- Click on the Attach File icon in the Annotations section.

- Click on the proof to where you'd like the attached file to be linked.

- Select the file to be attached from your computer or network.

- Select the colour and type of icon that will appear in the proof. Click OK.

E N D

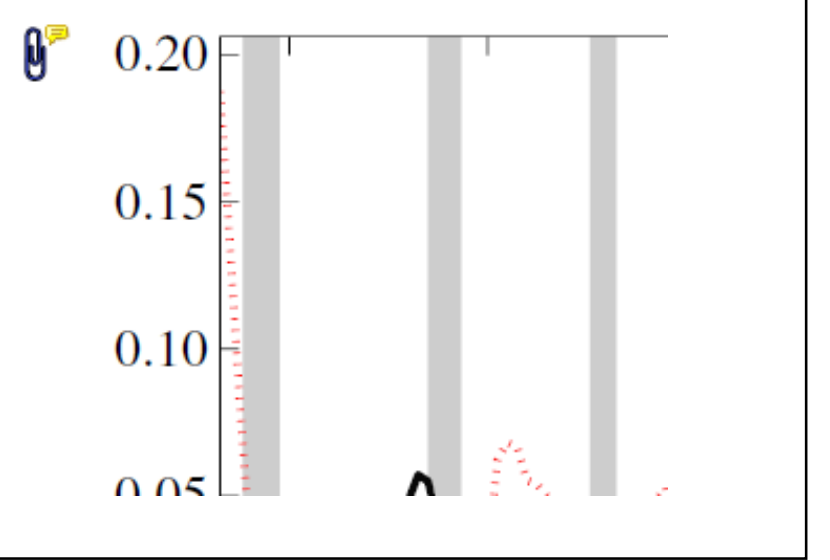

6. Add stamp Tool - for approving a proof if no corrections are required.

- Inserts a selected stamp onto an appropriate place in the proof

\section{How to use it}

- $\quad$ Click on the Add stamp icon in the Annotations section.

- $\quad$ Select the stamp you want to use. (The Approved stamp is usually available directly in the menu that appears).

- Click on the proof where you'd like the stamp to appear. (Where a proof is to be approved as it is, this would normally be on the first page).

of the Dusiness cycie, starting with the on perfect competition, constant ret

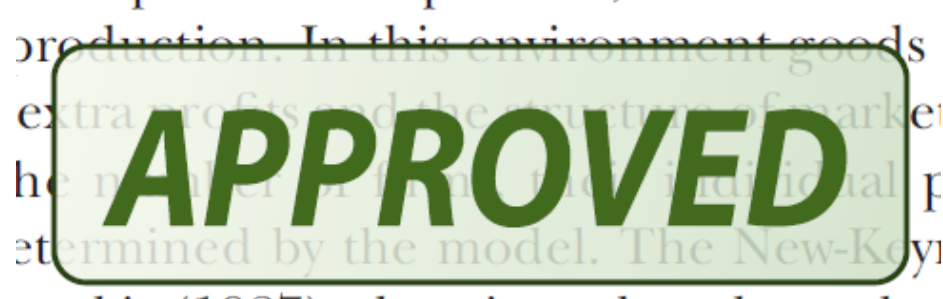

otaki (1987), has introduced produc general equilibrium models with nomin
- Drawing Markups

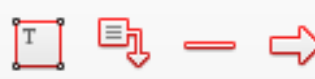

$0 \square \sqrt{6} D$

\section{How to use it}

- Click on one of the shapes in the Drawing Markups section.

- Click on the proof at the relevant point and draw the selected shape with the cursor.

- To add a comment to the drawn shape, move the cursor over the shape until an arrowhead appears.

- Double click on the shape and type any text in the red box that appears.
7. Drawing Markups Tools - for drawing shapes, lines and freeform annotations on proofs and commenting on these marks.

Allows shapes, lines and freeform annotations to be drawn on proofs and for comment to be made on these marks.

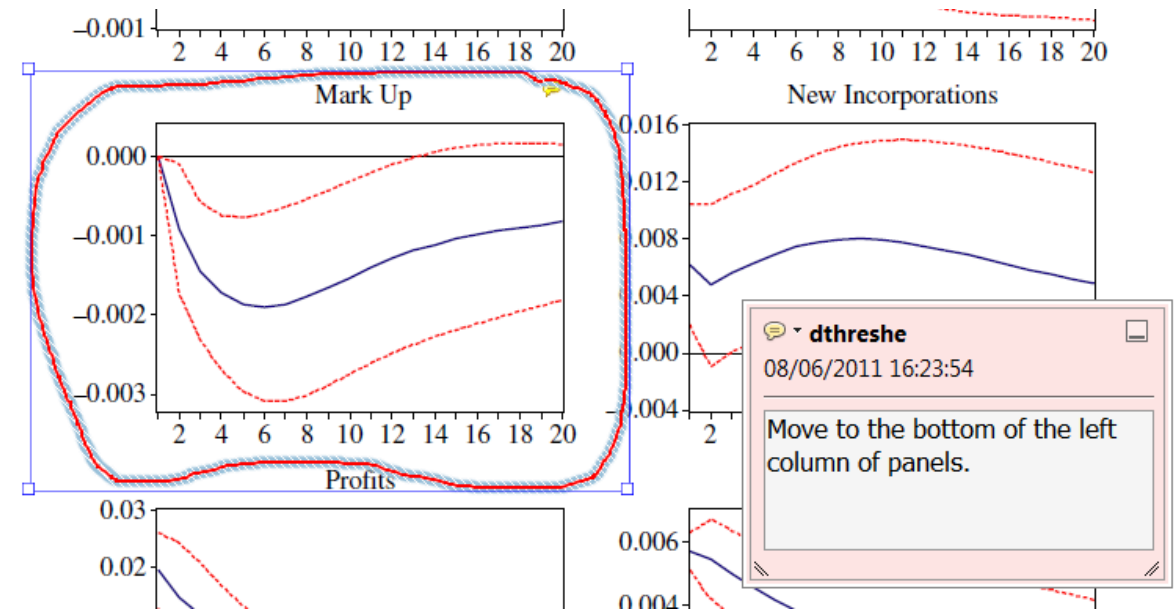

For further information on how to annotate proofs, click on the Help menu to reveal a list of further options:

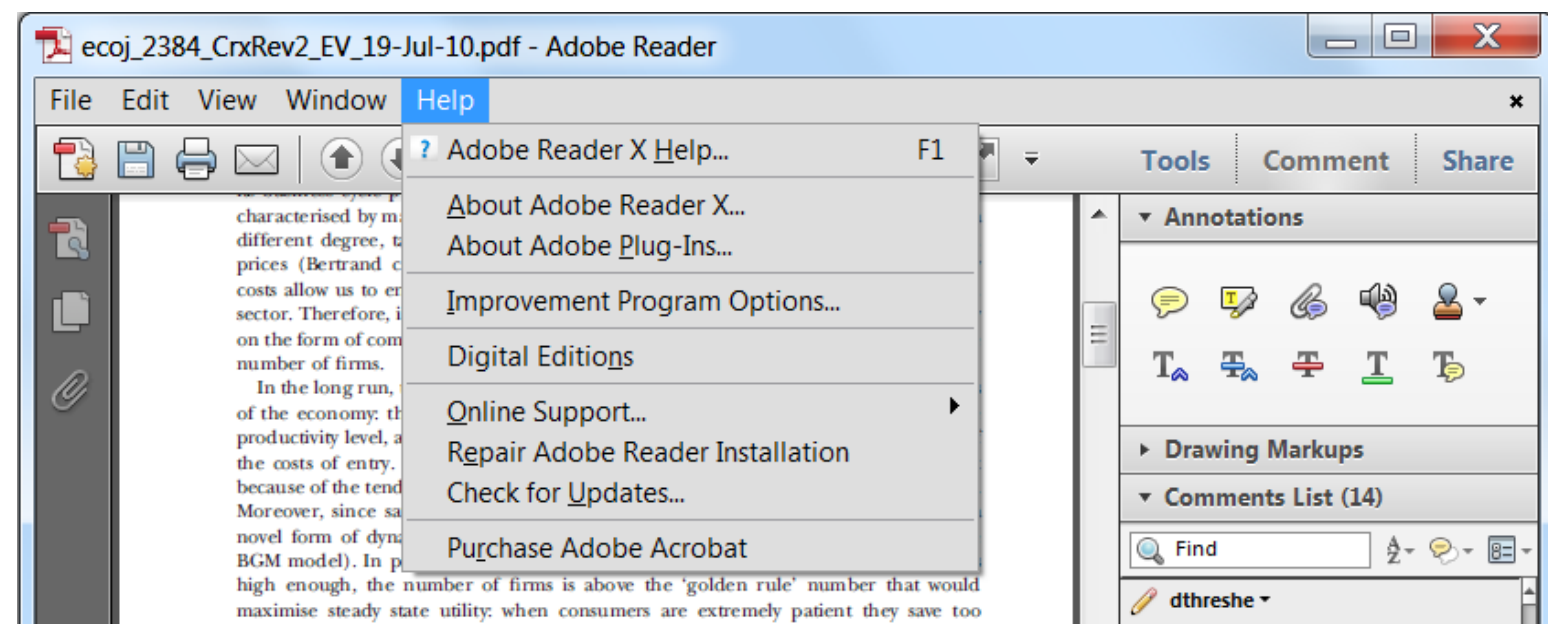

